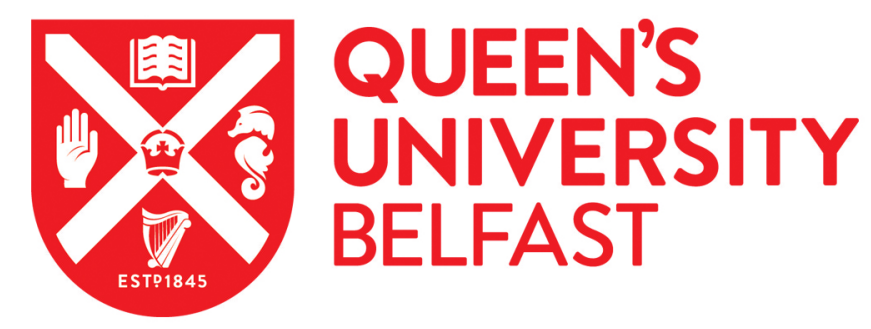

\title{
Arsenic accumulation in rice (Oryza sativa L.) is influenced by environment and genetic factors
}

Kumarathilaka, P., Seneweera, S., Meharg, A., \& Bundschuh, J. (2018). Arsenic accumulation in rice (Oryza sativa L.) is influenced by environment and genetic factors. The Science of the total environment, 642, 485-496. https://doi.org/10.1016/j.scitotenv.2018.06.030

\section{Published in:}

The Science of the total environment

\section{Document Version:}

Peer reviewed version

\section{Queen's University Belfast - Research Portal:}

Link to publication record in Queen's University Belfast Research Portal

\section{Publisher rights}

Copyright 2018 Elsevier.

This manuscript is distributed under a Creative Commons Attribution-NonCommercial-NoDerivs License

(https://creativecommons.org/licenses/by-nc-nd/4.0/), which permits distribution and reproduction for non-commercial purposes, provided the author and source are cited.

\section{General rights}

Copyright for the publications made accessible via the Queen's University Belfast Research Portal is retained by the author(s) and / or other copyright owners and it is a condition of accessing these publications that users recognise and abide by the legal requirements associated with these rights.

\section{Take down policy}

The Research Portal is Queen's institutional repository that provides access to Queen's research output. Every effort has been made to ensure that content in the Research Portal does not infringe any person's rights, or applicable UK laws. If you discover content in the Research Portal that you believe breaches copyright or violates any law, please contact openaccess@qub.ac.uk. 
1 Arsenic accumulation in rice (Oryza sativa $L$.) is influenced by environment and genetic

\section{factors}

Prasanna Kumarathilaka ${ }^{\mathrm{a}}$, Saman Seneweera ${ }^{\mathrm{b}}$, Andrew Meharg ${ }^{\mathrm{c}}$, Jochen Bundschuh, ${ }^{\mathrm{a},}$

${ }^{a}$ School of Civil Engineering and Surveying, Faculty of Health, Engineering and Sciences, University of Southern Queensland, Toowoomba, Queensland, Australia

${ }^{\mathrm{b}}$ Center for Crop Health, Faculty of Health, Engineering and Sciences, University of Southern Queensland, Toowoomba, Queensland, Australia

'Queen's University Belfast, Institute for Global Food Security, David Keir Building, Malone Road, Belfast, BT9 5BN, United Kingdom

2

3

$23 *$ Corresponding Author

24 Tele: +61746312694

25 Email: jochen.bundschuh@usq.edu.au 
Arsenic (As) elevation in soil will have a negative impact on both the yield and grain quality of rice (Oryza sativa L.). The mechanistic understanding of As uptake, translocation, and grain filling is an important aspect to produce rice grains with low As concentrations through agronomical, physico-chemical, and breeding approaches. In the paddy soil-water system, a range of physico-chemical, biological, and environmental factors governs the speciation of As and their concentrations. Major As transporters such as phosphate and aquaglyceroporins assimilate both inorganic (As(III) and As(V)) and organic As (DMA(V) and MMA(V)) species from the soil solution. A number of metabolic pathways (i.e., As (V) reduction, As(III) efflux, and As(III)-thiol complexation and sequestration) are likely to play a key role in determining the translocation and substantial accumulation of As species. The order of translocation efficiency (caryopsis-to-root) for As species in rice plants is as follows: $\operatorname{DMA}(\mathrm{V})>\operatorname{MMA}(\mathrm{V})>$ inorganic As species. The pattern of inorganic and organic As species loading into the grain is largely determined by the genetic makeup of the rice plants, maturity stage, and its environmental interaction. Therefore, the knowledge of As metabolism in rice plants and how it is affected by plant genetics, the environment, and its interactions would pave the way to developing adaptive strategies to mitigate the accumulation of As in rice grains.

Keywords: Arsenic speciation, Arsenic transporters, Arsenic metabolism, Detoxification, Grain filling, Arsenic toxicity 
53 3. Arsenic metabolism in rice plants

54 3.1. Uptake of inorganic Arsenic species 


\section{Introduction}

Rice (Oryza sativa) is the dominant dietary exposure route to arsenic (As), a non-threshold carcinogen. Rice grains can contain approximately 10-times as much as the baseline total of As when compared to other cereal grains (Williams et al., 2007). Rice and rice-based products can lead to an intake of excessive amount of inorganic As, particularly, in the populations in South and South-East Asia (Kile et al., 2007; Meharg et al., 2009). Rice is the primary source of As in a non-seafood diet in Europe and the United States (Fu et al., 2011).

Ohno et al. (2007) have demonstrated that rice contributed $56 \%$ of the total As intake; the corresponding figure for drinking water, solid food, liquid food, and cereals were 13, 11, 4.4, and $16 \%$, respectively. Contrasting results have also been reported elsewhere suggesting that drinking water has contributed to $93.5 \%$ of total As uptake, and rice and vegetables have only contributed to $6.2 \%$ and $0.3 \%$ of total As intake, respectively, in a groundwater contaminated Bangladeshi setting (Rahman et al., 2013).

Arsenic in the geological environment is mainly associated with sulfur (S) in minerals such as arsenopyrites (FeAsS), realgar $\left(\mathrm{As}_{4} \mathrm{~S}_{4}\right)$, and orpiment $\left(\mathrm{As}_{2} \mathrm{~S}_{3}\right)$ (Majzlan et al., 2014). Natural processes such as rock weathering, alluvial deposits may contribute As release into the paddy environment (Bundschuh and Maity, 2015; Herath et al., 2016). Anthropogenic activities (i.e., mining and use of As-contaminated groundwater in the form of irrigation water) promote the accumulation of natural As in paddy ecosystems. Moreover, Ascontaining insecticides, herbicides, feed additives, and wood preservatives are the potential anthropogenic sources of As in rice ecosystems (Chen et al., 2016b; Zhao et al., 2009).

$$
\text { Natural soils typically contain } 0.1 \text { to } 10 \mathrm{mg} \mathrm{kg}^{-1} \text { of total As (Zhao et al., 2010a). European }
$$
Community (EU) recommends that soils to be used for agricultural purposes should be 
contained less than $20 \mathrm{mg} \mathrm{kg}^{-1}$ of total As (Bhattacharya et al., 2009; Shrivastava et al., 2017). Arsenite (As(III)) and arsenate (As(V)) are the most commonly found inorganic As species whereas monomethylarsonoic acid (MMA(V)) and dimethylarsinic acid (DMA(V)) are the frequently reported organic As species in paddy soil-water systems (Honma et al., 2016; Jia et al., 2012). Both inorganic and organic As species are acquired by rice roots through various nutrient assimilatory pathways and they are translocated via a variety of mechanisms (Ma et al., 2008; Wang et al., 2016b).

\section{Attention is required to understand how rice plants take up and metabolize As species so} as to develop mitigation measures against this global contamination in the food chain. Taking these demands into account, this review presents recent progress in As dynamics in the rice ecosystem, and its uptake by rice roots and translocation to the rice grains. Further, mechanisms (i.e., metabolism/detoxification) that have evolved to mitigate the accumulation of As in rice tissues are discussed highlighting the major knowledge gaps that need to be addressed in future research.

\section{Arsenic phytoavailability in paddy soil-water system}

Paddy soils under conventional paddy management practices are subjected to flooded and non-flooded conditions, during initial and final stages of the growth of rice, respectively. The changes in water management regimes may alter redox potential (Eh) of the paddy soil-water systems (Pan et al., 2014). During flooded conditions, water replaces the gaseous phase in the soil matrix. A number of redox reactions (from high $\mathrm{Eh}(\sim+700 \mathrm{mV})$ to low $\mathrm{Eh}(\sim-300 \mathrm{mV})$ : reduction of $\mathrm{Mn}(\mathrm{IV}), \mathrm{Fe}(\mathrm{III})$, and $\mathrm{SO}_{4}{ }^{2-}$, and methanogenesis) take place either sequentially or simultaneously during this phase (Sahrawat, 2015). Arsenate in the soil matrix is converted to $\mathrm{As}(\mathrm{III})$, which is highly mobile than $\mathrm{As}(\mathrm{V})$, when Eh turns more negative. The 
$\mathrm{As}(\mathrm{III}) / \mathrm{As}(\mathrm{V})$ ratio is high in the soil solution during the flooded conditions and reverses for non-flooded conditions (Yamaguchi et al., 2014).

Iron (III) plaque, consisting of amorphous or crystalline Fe hydro(oxides) (FeOOH), has found to have a significant effect on the sequestration of both $\mathrm{As}(\mathrm{V})$ and $\mathrm{As}(\mathrm{III})$ (Eq. 1 and Eq. 2) (Liu et al., 2004). A higher ratio of $\mathrm{As} / \mathrm{Fe}$ in $\mathrm{Fe}(\mathrm{III})$ plaque around rice roots compared to that of Fe minerals in soil matrix indicates the high capacity of Fe(III) plaque for the retention of As in the rhizosphere (Yamaguchi et al., 2014). Radial oxygen loss (ROL), the process that diffuses $\mathrm{O}_{2}$ into the rhizosphere through root aerenchyma, promotes the formation of $\mathrm{Fe}(\mathrm{III})$ plaque under flooded conditions (Mei et al., 2009). Root anatomy (i.e., root porosity) in rice genotypes strongly correlates with ROL and substantial formation of Fe(III) plaque (Mei et al., 2009; Wu et al., 2011a). In addition, growth stage of rice plants and background Fe concentration in paddy soils have an effect on the quantity of Fe(III) plaque in rice roots ( $\mathrm{Li}$ et al., 2015). Therefore, As retention by $\mathrm{Fe}(\mathrm{III})$ plaque and subsequent accumulation of As in plant tissues (i.e., root, shoot, husk, and grain) of different rice genotypes are remarkably varied (Lee et al., 2013; Liu et al., 2006).

$$
\begin{aligned}
& \equiv \mathrm{FeOH}_{(s)}+\mathrm{AsO}_{4(a q)}^{3-}+3 \mathrm{H}_{(a q)}^{+} \rightarrow \mathrm{FeH}_{2} \mathrm{AsO}_{4(s)}+\mathrm{H}_{2} \mathrm{O}_{(l)} \\
& \equiv \mathrm{FeOH}_{(s)}+\mathrm{AsO}_{3(a q)}^{3-}+3 \mathrm{H}_{(a q)}^{+} \rightarrow \mathrm{FeH}_{2} \mathrm{AsO}_{3(s)}+\mathrm{H}_{2} \mathrm{O}_{(l)}
\end{aligned}
$$

Paddy soil consists of indigenous $\mathrm{FeOOH}$ including: ferrihydrite $\left(\mathrm{Fe}_{5} \mathrm{HO}_{8} 4 \mathrm{H}_{2} \mathrm{O}\right)$, goethite $(\alpha-\mathrm{FeOOH})$, lepidocrocite $(\gamma-\mathrm{FeOOH})$, and hematite $\left(\alpha-\mathrm{F}_{2} \mathrm{O}_{3}\right)$. Iron redox cycling $(\mathrm{Fe}(\mathrm{II})$ oxidation and $\mathrm{Fe}(\mathrm{III})$ reduction) has a significant impact on the mobility and bioavailability of As in paddy ecosystems (Yu et al., 2016b). Iron-reducing bacteria can convert Fe(III) to 


3

Fe(II) (Eq. 3) through two different pathways; dissimilatory reduction and assimilation reduction (Das et al., 2016; Qiao et al., 2017).

$$
\mathrm{FeOAs}(\mathrm{OH})_{2(s)} \rightarrow \mathrm{Fe}_{(a q)}^{2+}+\mathrm{AsO}_{3(a q)}^{3-}+2 \mathrm{H}_{(a q)}^{+}
$$

$$
\text { In contrast, Fe(II)-oxidizing bacteria may re-oxidize Fe(II) to Fe(III), particularly, under }
$$
non-flooded conditions. Since FeOOH has a strong affinity with both $\mathrm{As}(\mathrm{V})$ and $\mathrm{As}(\mathrm{III})$, it significantly reduces the mobility and bioavailability of As in paddy soil-water, and the subsequent uptake and accumulation of As in rice tissues (Yu et al., 2016b).

8

Recent studies have demonstrated that amorphous Fe oxide-bound As has played an important role in the sinking of As (Liu et al., 2015; Yu et al., 2016a). The conversion of poorly crystalline ferrihydrite (surface area: $100-700 \mathrm{~m}^{2} \mathrm{~g}^{-1}$ ) to other crystalline Fe oxides phases such as goethite (surface area: $\left.8-200 \mathrm{~m}^{2} \mathrm{~g}^{-1}\right)$ and hematite $\left(2-115 \mathrm{~m}^{2} \mathrm{~g}^{-1}\right)$ may decrease the sorption of As due to the reduction of adsorption sites. External supplementation of Fe (i.e., Fe oxides, mixed Fe sources, and Fe-rich industrial byproducts) can lead to reducing As burden in rice ecosystems for different reasons (Farrow et al., 2015; Yu et al., 2017). Firstly, Fe amendments may increase the percentage of amorphous Fe fraction in paddy soil. Secondly, Fe supplementation could increase the quantity of Fe(III) plaque deposited on root apoplast. Yu et al. (2017) have assessed the effect of Fe compound supplementation on As accumulation in rice tissues throughout the whole growth stages of rice plant and have found that $\mathrm{Fe}$ amendments significantly reduced the accumulation of As in rice tissues at the grain-filling stage. 
Nitrogen is one of the key nutrients, enhancing the growth of rice, and is supplied to paddy

174

175

\section{6} fields as $\mathrm{N}$ fertilizers (Ata-Ul-Karim et al., 2017). The process of Fe-redox cycling could be affected by nitrogen $(\mathrm{N})$ cycling (i.e., nitrification, denitrification, and ammonification) (Yu et al., 2016b). The coupled $\mathrm{NO}_{3}{ }^{-}$reduction and $\mathrm{Fe}$ (II) oxidation may reduce the fate of As in the paddy environment ( $\mathrm{Li}$ et al., 2012). Nitrate $\left(\mathrm{NO}_{3}{ }^{-}\right)$-dependent $\mathrm{Fe}(\mathrm{II})$-oxidizing bacteria can promote the oxidation of Fe(II) under flooded conditions as shown in Eq. 4 (Sun et al., 2009b). As described above, the higher the level of Fe(III), the lower the concentration of bioavailable As in paddy soil-water. The reduction of $\mathrm{Fe}(\mathrm{III})$ could be inhibited by $\mathrm{NO}_{3}{ }^{-}$ reduction because of their competition for electrons ( $\mathrm{Yu}$ et al., 2016b). Therefore, high level of $\mathrm{NO}_{3}^{-}$in paddy soil may decrease $\mathrm{Fe}(\mathrm{III})$ reduction and subsequent uptake and accumulation of As in rice tissues.

$$
\mathrm{Fe}_{(s)}^{2+}+5 \mathrm{H}_{2} \mathrm{O}_{(\mathrm{l})}+\mathrm{NO}_{3(a q)}^{-} \rightarrow 2 \mathrm{Fe}(\mathrm{OH})_{3(s)}+4 \mathrm{H}_{(a q)}^{+}+\mathrm{NO}_{2(a q)}^{-}
$$

Anammox-bacteria can drive the process of ammonia $\left(\mathrm{NH}_{3}\right)$ oxidation under anaerobic conditions. Ammonia oxidation is coupled with Fe(III) reduction as shown in Eq. 5 (Shrestha et al., 2009). However, the impact of $\mathrm{NH}_{3}$ oxidation on Fe-redox cycling in paddy ecosystem remains unclear.

$$
\mathrm{NH}_{4(a q)}^{+}+6 \mathrm{FeOOH}_{(s)}+10 \mathrm{H}_{(a q)}^{+} \rightarrow \mathrm{NO}_{2(a q)}^{-}+6 \mathrm{Fe}_{(s)}^{2+}+10 \mathrm{H}_{2} \mathrm{O}_{(l)}
$$

Organic fertilizer, added to keep paddy soil fertility, may influence As dynamics. Humic substances (i.e., humin, humic acid, and fulvic acid), which are key components of organic matter, have a positive and negative effect on the mobility and bioavailability of As (Jiang et al., 2009; Yu et al., 2016b). Arsenic species can be adsorbed to humic substances through 
204

205

206

219

organo-As complexes (Williams et al., 2011). In contrast, the process of adsorption of humic substances to sorption sites in soil matrix may increase the bioavailability of As in soil solution due to the site and electrostatic competitions (Mladenov et al., 2015). Humic substances could stimulate microbes-driven Fe(III) reduction by facilitating electron shuttling (Newman and Kolter, 2000). As a result, $\mathrm{As}(\mathrm{V})$, sequestrated in $\mathrm{FeOOH}$, may reduce to highly mobile As(III).

Sulfate $\left(\mathrm{SO}_{4}^{2-}\right)$ in soil matrix is reduced to sulfide $\left(\mathrm{S}^{2-}\right)$ when decreasing redox potential from -120 to $-180 \mathrm{mV}$ (Sahrawat, 2015). Sulfate-reducing bacteria can promote the reduction of $\mathrm{SO}_{4}^{2-}$ in paddy environment (Das et al., 2016). The reduction of $\mathrm{SO}_{4}^{2-}$ to $\mathrm{S}^{2-}$, particularly, under flooded conditions, leads to immobilization of As(III) due to precipitation of As(III), as arsenic sulfide, and iron sulfide minerals (Burton et al., 2014). External sulfur (S) supplementation may promote the formation of low molecular weight thiol-rich peptides in rice tissues, which have a high affinity with $\mathrm{As}(\mathrm{III})$, and therefore, may reduce As translocation from root to grain (Zhang et al., 2011).

(1)

Manganese oxides $(\mathrm{MnOH})$ play an important role in immobilizing As through oxidation of $\mathrm{As}(\mathrm{III})$ to $\mathrm{As}(\mathrm{V})$ and substantial complexation of $\mathrm{As}(\mathrm{V})$ (Eq. 6 and Eq. 7) (Lafferty et al., 2011). $\mathrm{Xu}$ et al. (2017b) have demonstrated that $\mathrm{MnOH}$, as an amendment (1200 $\left.\mathrm{mg} \mathrm{kg}^{-1}\right)$, has decreased the accumulation of As in rice straw and grains by $30-40 \%$.

$\mathrm{MnO}_{2(s)}+\mathrm{H}_{3} \mathrm{AsO}_{3(a q)}+2 \mathrm{H}_{(a q)}^{+} \rightarrow \mathrm{Mn}_{(a q)}^{2+}+\mathrm{H}_{3} \mathrm{AsO}_{4(a q)}+\mathrm{H}_{2} \mathrm{O}_{(l)}$

$2 \mathrm{Mn}-\mathrm{OH}_{(s)}+\mathrm{H}_{3} \mathrm{AsO}_{4(a q)} \rightarrow(\mathrm{MnO})_{2} \mathrm{AsOOH}_{(s)}+2 \mathrm{H}_{2} \mathrm{O}_{(l)}$ 
Bacteria, fungi, eukaryotic algae, and archaea, inhabiting in the rhizosphere, can influence

on the speciation of As through different biotransformation pathways: oxidation, reduction, methylation, and volatilization (Jia et al., 2012). A variety of genes in microorganisms encode for As-transformation enzymes and transporters. The process of microbial oxidation of As(III), coded for by aioA gene, can lead to producing As(V) (Zhang et al., 2015). In contrast, microbial $\mathrm{As}(\mathrm{V})$ reduction, coded for by $\operatorname{ars} C$ and $\operatorname{arr} A$ genes, may increase the mobility of As, particularly, under flooded conditions (Malasarn et al., 2004; Qiao et al., 2017; Villegas-Torres et al., 2011). Inorganic As species present in paddy ecosystems can be transformed into organic As species such as $\mathrm{MMA}(\mathrm{V})$, monomethylarsonous acid (MMA(III)), DMA(V), and dimethylarsinous acid (DMA(III)), and the process is coded for by arsM gene. For this reason, organic As species found in paddy soil-water are likely to be microbe-mediated products. Microorganisms can volatilize organic As to arsines, primarily as trimethylarsines $\left(\left(\mathrm{CH}_{3}\right)_{3} \mathrm{As}\right)$, with a smaller quantity of arsine $\left(\mathrm{AsH}_{3}\right)$, monomethylarsine $\left(\mathrm{CH}_{3} \mathrm{AsH}_{2}\right)$ and dimethylarsine $\left(\left(\mathrm{CH}_{3}\right)_{2} \mathrm{AsH}\right)$ (Hayat et al., 2017; Jia et al., 2012). As a result, microbes-driven As transformation may decrease the phytoavailability of As in paddy soilwater systems. Moreover, microorganisms can indirectly impact on the speciation and mobility of As by influencing Fe, $\mathrm{N}$, and $\mathrm{S}$ cycling, as discussed above. Recent findings have further revealed that soil amendments such as biochar may significantly affect the abundance and diversity of microorganisms, and the consequent transformation of As (Qiao et al., 2017; Qiao et al., 2018).

\section{Arsenic metabolism in rice plants}

Arsenic metabolism in different rice tissues is crucial for understanding uptake of inorganic and organic As species, their translocation, and grain filling. There are different genes involving in As metabolism including reduction, efflux, transformation, complexation 
and sequestration (Table 1). Fig. 1 illustrates genes associated with the uptake, translocation, and grain filling of inorganic and organic As species in the rice plant.

\subsection{Uptake of inorganic Arsenic species}

\subsubsection{Arsenite}

Arsenite, the main As species under flooded conditions, is acquired dominantly through nodulin 26-like intrinsic proteins (NIPs), collectively termed as aquaporin channels. In rice roots, OsNIP2;1, also called Lsi1, highly expressed in the distal side of the plasma membranes of the exodermis and endodermis cells where Casparian strips exist, is the major pathway for the influx of silicic acid $\left(\mathrm{Si}(\mathrm{OH})_{4}\right)$ as well as $\mathrm{As}(\mathrm{III})$ (as arsenous acid, $\left.\mathrm{As}(\mathrm{OH})_{3}\right)$ into rice roots (Fleck et al., 2013; Ma et al., 2008). This could be attributed to the similar sizes of both $\mathrm{Si}(\mathrm{OH})_{4}$ and $\mathrm{As}(\mathrm{OH})_{3}$ with tetrahedral orientation along with more or less similar dissociation constants ( $\left.p K_{a}\right)$ (9.2 and 9.3, respectively). Ma et al. (2008) demonstrated that NIP genes (OsNIP1;1 and OsNIP3;1) in oocytes mediate As(III) uptake but the $\mathrm{Si}(\mathrm{OH})_{4}$ pathway was unaffected. Rice OsNIP3;3 and OsNIP3;2 are highly expressed in the lateral roots and stele region of the primary roots suggesting that As(III) is taken up by the highly active part of the root system (Chen et al., 2017b; Katsuhara et al., 2014). In addition, plasma membrane intrinsic proteins (PIPs) such as OsPIP2;4, OsPIP2;6 and OsPIP2;7 are associated with the uptake of As(III) (Mosa et al., 2012) but their functional role is not well studied.

Aquaporin channel, OsNIP2;2 (Lsi2) being a $\mathrm{Si}(\mathrm{OH})_{4}$ efflux transporter, localized on the plasma membrane of cells in both the exodermis and endodermis of rice roots; however, contrary to Lsi1, Lsi2 is localized on the proximal side of the same cells. Preloading of the Xenopus oocytes with $\mathrm{Si}$ resulted in a release of Si back into the external environment, demonstrating that Lsi2 is a Si efflux transporter (Ma et al., 2007). Having an influx 
transporter on one side and an efflux transporter on the other side of the cell, As(III) cannot pass freely towards the stele (Zhao et al., 2010b). In addition to the Lsi2, As(III) efflux transporters are found in other organisms. For instance, Arsenic Compounds Resistance protein 3 (ACR3) in yeast extrudes As(III), however, ACR3 does not exist in flowering plants like rice. Meng et al. (2011) found that the introduction of ACR3 (ScACR3) into rice decreased total As concentration in rice grains by nearly $20 \%$ suggesting that the transgenic rice plant extruded As(III) back into the external environment. In this aspect, As(III) efflux is a key mechanism which releases a portion of $\mathrm{As}(\mathrm{III})$ into the external environment minimizing cellular As accumulation.

In some plant species, uptake of $\mathrm{As}(\mathrm{III})$ is a bi-directional process; the direction is determined by the concentration gradient. For instance, aquaporins from different plant species such as Pteris vittata (PvTIP4;1), Lotus japonicas (LjNIP5;1 and LjNIP6;1), and Arabidopsis thaliana (AtNIP1;1, AtNIP1;2, AtNIP3;1, AtNIP5;1, AtNIP6;1, and AtNIP7;1) are known to be associated with As(III) efflux into the external environment (Bienert et al., 2008; He et al., 2016; Kamiya and Fujiwara, 2009; Xu et al., 2015). In this sense, a transgenic approach, overexpressing As(III) efflux transporters is likely to mitigate the accumulation of As in rice tissues.

Following the uptake, besides the As(III) efflux, As(III) has a high affinity for thiol-rich peptides such as glutathione (GSH) and phytochelatins (PCs) that are derived from GSH with the general structure $(\gamma-$ Glu-Cys)n-Gly $(n=2-11)$ in the rice roots. Overexpression of the PCs leads to As resistance in transgenic plants, increasing the level of As in roots, but a remarkably low level of As in rice grains (Shri et al., 2014). After being formed, As(III)-PC complexes are transported into vacuoles for the sequestration by C-type ATP-binding cassette 
transporter (OsABCC1) which is expressed in the exodermis and pericle. Similarly, it has been reported that $\mathrm{AtABCC} 1$ and $\mathrm{AtABCC} 2$ in Arabidopsis thaliana mediate the transportation of As(III)-PC complexes into the vacuole (Song et al., 2010). The favorable pH (approximately 5.5) in vacuoles may provide an ideal condition for the stability of As(III)-PC complexes (Zhao et al., 2009). Therefore, vacuole sequestration of As(III)-PC complexes plays an important role in alleviating the translocation of As(III) into the rice grain.

Gene expressions associated with As(III) assimilation (As(III) influx and efflux) are largely varied with the developmental stages of the rice plant and cultivar type. A recent study by $\mathrm{Wu}$ et al. (2017) demonstrated that expression of Lsi1 and Lsi2 genes were significantly down-regulated in non-flooded conditions compared to flooded conditions. These genes are strongly associated with As assimilation and it might be one of the major factors that suppress the accumulation of As under non-flooded conditions. It has been found that a mutation in Lsi1 remarkably reduced the uptake and accumulation of As(III) in rice shoots and grains (Ma et al., 2008). Similarly, Guo et al. (2009) demonstrated that a Sidefective mutant in rice plant showed a decrease in As(III) uptake (Guo et al., 2009). Therefore, understanding the temporal distribution of As species and expression of genes across As efficient and inefficient cultivars are paramount for developing mitigation measures of As in rice.

Rice plants are an efficient $\mathrm{Si}$ accumulator and can contain $\mathrm{Si}$ in shoots about $10 \%$ of shoot dry weight (Meharg and Meharg, 2015). In this regard, supplementation of Si fertilizers to As-contaminated paddy soils may provide an effective strategy to minimize As(III) uptake (Guo et al., 2007; Seyfferth and Fendorf, 2012). It has been reported that Si application to the paddy soil, decreased the total As concentration by 33\% in rice grains (Fleck et al., 2013). A 
similar study by Wang et al. (2016a) showed that high Si application rates (9000 $\left.\mathrm{kg} \mathrm{ha}^{-1}\right)$ decreased the total As concentration in rice grains by $20 \%$. Thus, Si application to Ascontaminated paddy soils is beneficial for rice plants, partly because of the decreased uptake of As(III) by rice roots, and partly because of the increased plant resistance to biotic and abiotic stresses.

\subsubsection{Arsenate}

Arsenate is the most prevalent As species under non-flooded paddy soils. Physiological and electrophysiological studies have revealed that $\mathrm{As}(\mathrm{V})$ and $\mathrm{PO}_{4}{ }^{3-}$ share the same uptake pathway (Muehe et al., 2014). In the rice genome, $13 \mathrm{PO}_{4}{ }^{3-}$ transporter genes (OsPHTs) have been identified; however, their response to $\operatorname{As}(V)$ and contribution to $A s(V)$ uptake in rice have not been studied in detail yet.

Phosphate transporter, OsPHT1;8 (OsPT8), was found to have a high affinity for both $\mathrm{PO}_{4}{ }^{3-}$ and $\mathrm{As}(\mathrm{V})$ uptake in rice. The overexpression of the OsPT8 has increased the maximum influx of $\mathrm{As}(\mathrm{V})$ by 3 - 5 times in rice plants (Wang et al., 2016b; Wu et al., 2011b). The $\mathrm{PO}_{4}{ }^{3-}$ transporter gene, OsPHT1;1, also mediates the uptake of As(V) into the rice roots (Kamiya et al., 2013). It has been found that other plant species may contain $\mathrm{PO}_{4}{ }^{3-}$ transporters which are mediating $\mathrm{As}(\mathrm{V})$ uptake. For example, $\mathrm{PO}_{4}{ }^{3-}$ transporters, such as PvPht1;3 in Pteris vittata and AtPHT1;1, AtPHT1;4, AtPHT1;5, AtPHT1;7, AtPHT1;8, and AtPHT1;9 from Arabidopsis thaliana acquire As(V) from the rhizosphere (DiTusa et al., 2016; Fontenot et al., 2015; Shin et al., 2004). enzymes play a key role in controlling the conversion of $\mathrm{As}(\mathrm{V})$ to $\mathrm{As}(\mathrm{III})(\mathrm{Xu}$ et al., 2007). 
Efficient $\mathrm{As}(\mathrm{V})$ reduction takes place in all tissues of the root apex which was supported by fluorescence-X-ray absorption near-edge spectroscopy (XANES) analysis (Batista et al., 2014). Recently, Shi et al. (2016b) identified two As(V) reductases, OsHAC1;1 (abundant in the epidermis, root hairs, and pericycle cells) and OsHAC1;2 (abundant in the epidermis, outer layers of cortex, and endodermis cells) which play an important role in the reduction of $\mathrm{As}(\mathrm{V})$ to $\mathrm{As}(\mathrm{III})$ in rice roots.

Interestingly, As(III) is found in considerable concentrations in plant roots exposed to $\mathrm{As}(\mathrm{V})$. However, after the reduction of $\mathrm{As}(\mathrm{V}), \mathrm{As}(\mathrm{III})$ can be released into the external environment via As(III) efflux system or complexed with thiol compounds as mentioned earlier. A new As(V) reductase, OsHAC4, has been identified and it is highly expressed in the epidermis and exodermis of roots, the location which is ideal for the efflux of As(III) to the external environment (Xu et al., 2017a). Similar As(V) reductases, namely As(V) tolerance QTL1 (ATQ1) and High Arsenic Content 1 (HAC1) were identified in Arabidopsis thaliana (Chao et al., 2014). Therefore, the reduction of As(V) to As(III) and subsequent As(III) efflux or As(III)-thiol complexation in rice roots are likely to play a major role in determining the level of total As in rice grains.

Since $\mathrm{As}(\mathrm{V})$ is an analogue for $\mathrm{PO}_{4}{ }^{3-}$ in plant uptake process, the application of external $\mathrm{PO}_{4}{ }^{3-}$ to the As-contaminated paddy soil could alleviate the accumulation of $\mathrm{As}(\mathrm{V})$ in rice tissues (Lihong and Guilan, 2009). Studies have clearly demonstrated that the supplementation of $\mathrm{PO}_{4}{ }^{3-}$ fertilizers to the As-contaminated paddy soils has greatly decreased the concentration of total As in rice grains (Geng et al., 2005). Excess supplementation of $\mathrm{PO}_{4}{ }^{3-}$ fertilizers may lead to eutrophication in surface water bodies. Therefore, a close monitoring must be carried out under excess usage of $\mathrm{PO}_{4}{ }^{3-}$ fertilizers. 


\subsection{Uptake of organic As species}

Rice plants are not capable of methylating inorganic As in vivo, therefore, organic As species (DMA(V) and MMA(V)) are probably come from the rhizosphere through microbialmediated methylation processes (Jia et al., 2012; Zhao et al., 2013a). The exact mechanisms that drive the uptake of organic As species in rice are largely unknown. It has been suggested that aquaporin Lsil mediates the uptake of undissociated MMA(V) and DMA(V) in rice plants (Li et al., 2009). The $\mathrm{pH}$ of the medium has a great effect on the uptake of MMA(V) and $\mathrm{DMA}(\mathrm{V})$. More precisely, $\mathrm{pH}$ can alter the equilibrium between protonation and dissociation that eventually influence the availability of the MMA(V) and DMA(V) for the membrane transporter, Lsi1 (Li et al., 2009). Therefore, Lsil plays a major role in acquiring both inorganic As(III) and organic As species from the rhizosphere.

\section{There have been not many reports on the metabolism of organic As species in rice roots. A} recent study by Mishra et al. (2017) revealed that MMA(V) is readily reduced into MMA(III) which is then bound with thiols in rice roots. In addition, MMA(V) itself can complex with various thiol groups in rice plants. Mishra et al. (2017) found that 16 different MMA(V)-thiol complexes were present in the rice root and shoot. However, DMA(V) is known to neither complex with thiols or convert into the reduced forms. The direct determination of organic As species - thiol complexation in various rice genotypes is an important step for understanding As metabolism in rice plants.

\subsection{Arsenic species translocation from root to shoot}

It is likely that both active and passive transporters are associated with the uptake and translocation of As in rice plants. Active transportation is the process of passing materials against a concentration gradient by using the energy of metabolism (Liang et al., 2006). 
Passive transport is the movement of water and materials without using the energy of metabolism and mainly transport through transpiration flow. For example, a large number of nutrients such as potassium $(\mathrm{K})$, nitrogen $(\mathrm{N}), \mathrm{Si}$, is transported through both active and passive processes in rice plants (Bao et al., 2015; Yang et al., 2014). Following the uptake by rice root, various transporters and compounds have involved the translocation of As species from root to shoot.

The translocation of inorganic As species from root to shoot is determined by various processes. Lsi2 mediates the efflux of uncomplexed As(III) in the direction of xylem. In addition, the Natural Resistance-Associated Macrophage Protein (NRAMP) transporter, OsNRAMP1, may also facilitate the xylem loading of As(III) (Tiwari et al., 2014). Different metabolic activities such as As(III) efflux back into the external environment, and formation of As(III)-thiol complexes and consequent sequestration in vacuoles, limit the translocation of As(III) from root to shoot. Studies have revealed that rice cultivars with low levels of total As in their grains had remarkably higher concentrations of PCs in roots compared to the cultivars with high total As levels in their grains (Duan et al., 2011). In contrast, Batista et al. (2014) found that PCs produced in rice cultivars in response to elevated levels of As exposure did not necessarily reduce the total As concentrations in rice grains.

The translocation efficiency of organic As species from root to shoot is much higher than that of inorganic As species (Raab et al., 2007). It could be attributed to the favorable dissociation of MMA(V) and $\mathrm{DMA}(\mathrm{V})$ at cytoplasmic $\mathrm{pH}$. Since MMA(V) is partly reduced to MMA(III), only untransformed MMA(V) is transported to the shoots (Li et al., 2009). In addition, the lack of DMA(V)-PC complexation enhances the DMA(V) to be readily moved between root and shoots (Zhao et al., 2013b). Putative peptide transporter in rice, OsPTR7, 
422 involve in the long-distance (root to grain) translocation of organic As species in rice. The

423 OsPTR7 transcript is more prevalent in the leaves, nodes, and roots at the flowering and grain

424 filling stage; however, during the seedling stage, OsPTR7 is more abundant in the shoots than

425 in the roots (Tang et al., 2017).

426

427

There have been no reports of volatile As species released by rice plants under typical growing conditions. However, a large amount of volatile As is released from paddy soil due to microbial activities. The volatilization of $\left(\mathrm{CH}_{3}\right)_{3} \mathrm{As}$ from rice plants grown in an axenic system was detected when rice plants were treated with trimethylarsine oxide $\left(\left(\mathrm{CH}_{3}\right)_{3} \mathrm{AsO}\right)$ but not with other inorganic or organic As species (Jia et al., 2012). A soil bacterium, Rhodopseudomonas palustris, is found to have a direct influence on As volatilization. When an arsM gene from Rhodopseudomonas palustris was expressed in rice, transgenic rice produced volatile arsenicals (i.e., $\left.\left(\mathrm{CH}_{3}\right)_{3} \mathrm{As}\right)$ which were 10 times greater than that of the control (Meng et al., 2011). Therefore, producing transgenic rice plants with arsM gene could be adapted to mitigate the As burden in rice plants by achieving As volatilization out of the rice crop.

3.4. Phloem and xylem - derived pathways of As species transport

A recent study by Ye et al. (2017) revealed that As(III) was the prevalent As species $(69 \%)$ in the phloem exudates of $\mathrm{As}(\mathrm{III})$-exposed rice, while $\mathrm{As}(\mathrm{V})$ dominated (58\%) in $\mathrm{As}(\mathrm{V})$-exposed rice and the remainder was As(III). When rice plants were treated with $\operatorname{MMA}(\mathrm{V})$ and $\mathrm{DMA}(\mathrm{V})$, the major As species in phloem exudates were 55 and $59 \%$ of MMA(V) and DMA(V), respectively. Interestingly, a large proportion of As(V) (45 and 41\%, respectively) was detected in the phloem exudates when rice was treated with MMA(V) and 
DMA(V). This observation could correspond to the demethylation process; however, the mechanisms underlying demethylation remain unclear.

Phloem transportation is likely to be responsible for $54,56,100$, and $89 \%$ of As(III), $\mathrm{As}(\mathrm{V}), \mathrm{MMA}(\mathrm{V})$, and $\mathrm{DMA}(\mathrm{V})$ transport into the rice grain, respectively. Organic As species are more mobile than inorganic As species in the phloem as described by Ye et al. (2017). et al. (2010) accounted the phloem transport to be responsible for 90 and $55 \%$ of transportation of As(III) and DMA(V) to the grain, respectively. The difference in the above two studies could be attributed to the experimental methods used. Stem girding, which blocks phloem transportation, has reduced grain ${ }^{73} \mathrm{As}$ radioactivity by $97 \%$ compared to the ungirdled control (Zhao et al., 2012). Therefore, it can be suggested that phloem acts as the primary route of transport to rice grains for both inorganic and organic As species. Transporters responsible for As species loading into the vascular tissues in rice plant are need to be investigated in detail. Inositol transporters (INT) such as AtINT2 and AtINT4 are associated with phloem loading of As(III) in Arabidopsis thaliana (Duan et al., 2016) and similar transporters might responsible for phloem loading of As(III) transport in rice.

Synchrotron $\mu \mathrm{X}$-ray fluorescence $(\mu$-XRF) mapping has indicated that As(III) was sequestrated in the phloem, top node, and internode, limiting As(III) loading into the rice grain. The OsABCC transporter, which is expressed in the tonoplast of phloem in nodes, enhances the transportation of As(III)-PC complexes to vacuoles (Song et al., 2014). The knockout mutant of OsABCC has decreased the level of total As in nodes but has increased the level of total As in grains. Therefore, it is likely that rice plants have evolved a mechanism to minimize As loading into their grains. 
There are only few reports discussing the transportation of As species through xylem in rice plants. Arsenic(III) is the prevalent form of As present in the xylem of Pteris vittata and Cucumis sativus (Mihucz et al., 2005; Su et al., 2008). The predominant As species in the xylem sap of rice is vary with water management practices. Ye et al. (2015) found that As $(V)$, accounting for $64-88 \%$, was the dominant form of As in the xylem sap of rice under aerobic treatment. In contrast, in the flooded treatment, the prevalent species in the xylem sap 477 in rice was As(III), accounting for $26-77 \%$, followed by As(V) (12 - $54 \%$ ) and DMA(V) (11- $20 \%$ ) (Ye et al., 2015). Highly expressed Si pathway may load more As(III) into the xylem, in particular, in the flooded cultivation of rice.

3.5. Arsenic species loading into the grain

Arsenic species loading into rice grain is particularly important since it leads to the primary pathway of As exposure in human beings. From the available data, it is clear that there are significant site and genotype interactions on the distribution and concentration of As species in rice grains (Norton et al., 2009; Sommella et al., 2013). DMA(V) translocates from root to rice grain more efficiently (approximately 10-fold greater) compared to inorganic As species (Carey et al., 2010). As mentioned earlier, lack of complexation of DMA(V) may promote the efficient movement of $\mathrm{DMA}(\mathrm{V})$ in rice plants. The re-translocation of $\mathrm{DMA}(\mathrm{V})$ and MMA(V) from the flag leaf into the filling grain is more efficient than that of $\mathrm{As}(\mathrm{V})$ and As(III) which are not detectable even leaves were fed with As(III). The formation and subsequent sequestration of $\mathrm{As}(\mathrm{III})-\mathrm{PC}$ complexes in rice leaves may restrict the $\mathrm{As}(\mathrm{III})$ from loading into the phloem and subsequent translocation to the rice grain (Zheng et al., 2011). organic As species loading into the grain. As(III) is mostly retained in the ovular vascular 
trace (OVT) region, the vascular entry point into the rice grain and comprises of phloem and

497 xylem cells, whereas DMA(V) disperses throughout the outer layers and into the endosperm

498

499

500

501

502

503

504

505

506

507

508

509

510

511

512

513

514

515

516

517

518

519

520

(Carey et al., 2010). It is suggested that DMA(V) in the rice grain is derived from the retranslocation of $\mathrm{DMA}(\mathrm{V})$ accumulated before flowering. In contrast, inorganic As species mainly transport to the rice grain during flowering. In this respect, DMA(V) would accumulate at considerable concentrations in the initial stage of grain filling and later is diluted by carbohydrate filling to the grain (Zheng et al., 2011). This is exemplified by Carey et al. (2012) that the direct shoot-to-grain translocation is during grain filling and not from vegetative stores that is responsible for inorganic As in rice grains. Relatively higher As concentrations in bran than in polished grain could be due to following reasons: firstly, the bran acts as a physiological barrier for As translocation into the rice grain, secondly, As is likely to be concentrated in the protein-rich tissues including embryo and aleurone layer. So far, none of the studies has shown any effort towards the quantitative determination of As species in different layers of the rice grain under different growing stages, water management regimes, and with supplementation of nutrients and amendments in As-contaminated paddy environment.

\subsection{Translocation efficiency of arsenic species}

The highest translocation efficiency (caryopsis-to-root) in rice was reported for DMA(V) followed by MMA(V) and inorganic As species (Geng et al., 2017; Jia et al., 2012). The order of translocation efficiency differs in various parts of the rice tissues. Dittmar et al. (2010) showed that the straw to grain transfer factor declined exponentially with increasing the concentration of total As in straw and eventually reached a constant value $(\sim 0.04)$. The high yielding rice cultivars tend to have a high efficiency of translocation than the rice cultivars with low yielding capacity (Bhattacharya et al., 2010; Zheng et al., 2011). 
521 Regardless of the location and season, total As concentrations in rice tissues decreased in the order: root $>>$ shoot $>$ straw $>$ husk $>$ grain (Table 2 and 3$)$.

523

Agronomic practices greatly influence the speciation and accumulation and speciation of As in rice grains. The dynamics of total As in rice grain under both flooded and non-flooded conditions revealed that total As concentrations in rice grains were $10-15$ times greater in rice grown under flooded conditions than in rice grown under non-flooded conditions $(\mathrm{Xu}$ et al., 2008). This is consistent with the study by Spanu et al. (2012) who showed that intermittent irrigation has produced rice grains with $2.8 \mu \mathrm{g} \mathrm{kg}^{-1}$ of total As whereas the corresponding figure for continuous flooding irrigation was $163 \mu \mathrm{g} \mathrm{kg}^{-1}$. Correlation analysis revealed that a significant positive correlation existed in total As concentrations between soil pore water and rice grains. Similarly, studies have indicated that an increased level of soil As lead to high level of total As in rice straw and grains (Dittmar et al., 2010; Hossain et al., 2008). However, contradicting results have also been reported and these could be due to various factors including irrigation intensity, underlying geology, weather conditions, fertilizer applications, and diseases.

\section{Arsenic risk to rice plant and humans}

\subsection{Impact on yield}

Straighthead disease, in which the panicles remain upright due to lack of grain filling and sterility, is most common in rice due to a high level of As exposure ( $\mathrm{Li}$ et al., 2016). Both chlorophyll $\mathrm{a}$ and $\mathrm{b}$ levels in rice leaves tend to decrease under As exposure and this may adversely affect the photosynthesis (Rahman et al., 2007a). Increased level of As(V) in paddy soil pore water negatively affects plant growth parameters including plant height, grain yield, number of filled grains, and root biomass. Further, accumulation of $\mathrm{As}(\mathrm{V})$ and $\mathrm{As}(\mathrm{III})$ 
enhances the production of reactive oxygen species (ROS) which damage macromolecules

547 and cell membranes (Finnegan and Chen, 2012). A recent study by $\mathrm{Xu}$ et al. (2017a) demonstrated that As(III) binds with reduced cysteine residues in proteins, hence, influence the catalytic functions. Moreover, the preferential translocation of DMA(V) into filial tissues such as embryo, endosperm, and aleurone causes marked reduction in seed setting rate (i.e., spikelet sterility) and loss of yield (Wang et al., 2015). Rice cultivation in an environment with minimal As level or As-tolerance rice cultivars are, therefore, an important aspect of achieving the goal of sustainable production of rice in terms of quality and quantity.

4.2. Contribution of rice to arsenic intake in humans

Rice and rice-based products with high As concentrations may increase health risk for the humans (Sandhi et al., 2017; Signes-Pastor et al., 2016). The level of total As and As species in rice grains are depended on the rice genotype, physico-chemical, and environmental interactions as summarized in Table 4. Arsenic-containing rice husks are used as cattle feed in several countries (i.e., Bangladesh and China) and may act as an indirect pathway of As exposure to humans through the food chain (Abedin et al., 2002). In addition, As in rice grains leads to the loss of trace mineral nutrition such as $\mathrm{Zn}$, Se, and $\mathrm{Ni}$ and amino acid content (Dwivedi et al., 2010; Williams et al., 2009a). High levels of As in rice bran increases the risk, particularly for children, and people on gluten-free products (Abedin et al., 2002). Removing the bran layer during rice processing is an effective way to elimination of inorganic As. However, from a nutritional point of view, removal of the bran results in a substantial loss of nutrients in rice grains.

There have been many studies focusing on the risk assessment of human exposure to As. For example, the lifetime cancer risk in West Bengal, India was found to be $7.62 \times 10^{-4}$ which 
571 exceed the United States Environmental Protection Agency (USEPA) threshold value of $10^{-4}$ $572-10^{-6}$ (Mondal and Polya, 2008). Dittmar et al. (2010) predicted that under current irrigation

573 practices in Bangladesh, total As concentration in rice grains would increase from $\sim 0.15$ to $5740.25-0.58 \mathrm{mg} \mathrm{kg}^{-1}$ by 2050 . This figure increases the human As intake by $1.5-3.8$ fold 575 through rice. Therefore, precautionary measures must be undertaken to control the intake of 576 As from rice considering special attention to regions prone to As contamination.

\section{Concluding remarks}

Arsenic dynamics in paddy soil-water and rice grains are a function of geochemical, microbial and plant genetic factors. The knowledge gained with respect to speciation, mobility, and bioavailability of As in paddy soil-water, and subsequent uptake, efflux, translocation, and sequestration of As is important to develop mitigation measures. Rice production is required to be increased to meet the demand for ever-growing populations. Therefore, there is an urgent need to adapt As mitigation measures in As-prone areas in the world to reduce As burden. Firstly, the mobility and bioavailability of As in paddy-soil water system could be decreased by using agronomical, physico-chemical, and biological approaches. Alternative water management practices may play an important role in reducing As mobility and bioavailability in paddy environment due to changes in redox chemistry. Supplementation of fertilizer and soil amendments can lead to reducing the bioavailability of As for rice plants. Optimum supplementation rates of fertilizer and soil amendments are required to be investigated before introducing them to As-contaminated paddy lands. Microorganisms are a key factor influencing As mobility and bioavailability in paddy soilwater system through direct and indirect pathways. The kinetics of microbes-driven As biotransformation and related rate limiting factors are needed be examined with respect to different As-contaminated localities. Secondly, uptake and translocation of As species in rice 
596

597

598

599

600

601

602

603

604

605

606

607

608

609

610

611

612

613

614

615

616

0

plant could be decreased by altering the expression of transporters associated with the uptake, efflux, translocation, and sequestration of As. It is important to study in detail whether changes in expression of transporters related to As metabolism are impact on the uptake and translocation of other essential elements and compounds in rice plants.

Questions regarding the uptake and translocation of As species in rice plants remain unanswered and must be the aim of future studies. These include the following: (1) the extent of active and passive As uptake and translocation in rice, (2) a detailed survey of possible As demethylation and volatilization mechanisms and identify related genes involving in As demethylation and volatilization rice tissues, (3) the spatial distribution of As species and temporal variations of their concentrations in rice grain at development stages in various rice genotypes under different water management regimes and soil amendments, and (4) determination of As-thiol complexes qualitatively and quantitatively in different rice cultivars at different growing stages.

As-containing rice grains are a major source of As, particularly, for those consuming a large amount of rice and rice-based products. The development of advanced technologies to an in-situ measurement of As species and associated elements and genes at cellular and subcellular levels in rice plants is significantly important to identify rice grains for safe consumption. Therefore, scientific-based studies in As dynamics safeguard the paddy rice ecosystems and human from the As burden. 


\section{References}

Abedin, M.J., Cresser, M.S., Meharg, A.A., Feldmann, J., Cotter-Howells, J., 2002. Arsenic accumulation and metabolism in rice (Oryza sativa L.). Environ. Sci. Technol. 36, 962968.

Adeyemi, J.A., Adedire, C.O., Martins-Junior, A.D.C., Paulelli, A.C., Awopetu, A.F., Segura, F.R., de Oliveira-Souza, V.C., Batista, B.L., Barbosa Jr, F., 2017. Arsenic speciation in rice consumed in south-western Nigeria, and estimation of dietary intake of arsenic species through rice consumption. Toxicol. Environ. Chem. 99, 1-8.

Ata-Ul-Karim, S.T., Liu, X., Lu, Z., Zheng, H., Cao, W., Zhu, Y., 2017. Estimation of nitrogen fertilizer requirement for rice crop using critical nitrogen dilution curve. Field Crop. Res. 201, 32-40.

Bao, A., Liang, Z., Zhao, Z., Cai, H., 2015. Overexpressing of OsAMT1-3, a high affinity ammonium transporter gene, modifies rice growth and carbon-nitrogen metabolic status. Int. J. Mol. Sci. 16, 9037-9063.

Batista, B.L., Nigar, M., Mestrot, A., Alves Rocha, B., Barbosa Junior, F., Price, A.H., Raab, A., Feldmann, J., 2014. Identification and quantification of phytochelatins in roots of rice to long-term exposure: evidence of individual role on arsenic accumulation and translocation. J. Exp. Bot. 65, 1467-1479.

Bhattacharya, P., Samal, A., Majumdar, J., Santra, S., 2009. Transfer of arsenic from groundwater and paddy soil to rice plant (Oryza sativa L.): a micro level study in West Bengal, India. World J. Agri. Sci. 5, 425-431.

Bhattacharya, P., Samal, A., Majumdar, J., Santra, S., 2010. Accumulation of arsenic and its distribution in rice plant (Oryza sativa L.) in Gangetic West Bengal, India. Paddy Water Environ. 8, 63-70. 
Bienert, G.P., Thorsen, M., Schüssler, M.D., Nilsson, H.R., Wagner, A., Tamás, M.J., Jahn, T.P., 2008. A subgroup of plant aquaporins facilitate the bi-directional diffusion of $\mathrm{As}(\mathrm{OH})_{3}$ and $\mathrm{Sb}(\mathrm{OH})_{3}$ across membranes. BMC Biol. 6, 26.

Bogdan, K., Schenk, M.K., 2008. Arsenic in rice (Oryza sativa L.) related to dynamics of arsenic and silicic acid in paddy soils. Environ. Sci. Technol. 42, 7885-7890.

Bundschuh, J., Maity, J.P., 2015. Geothermal arsenic: occurrence, mobility and environmental implications. Renew. Sust. Energ. Rev. 42, 1214-1222.

Burton, E.D., Johnston, S.G., Kocar, B.D., 2014. Arsenic mobility during flooding of contaminated soil: the effect of microbial sulfate reduction. Environ. Sci. Technol. 48, 13660-13667.

Carbonell-Barrachina, Á.A., Wu, X., Ramírez-Gandolfo, A., Norton, G.J., Burló, F., Deacon, C., Meharg, A.A., 2012. Inorganic arsenic contents in rice-based infant foods from Spain, UK, China and USA. Environ. Pollut. 163, 77-83.

Carey, A.-M., Lombi, E., Donner, E., de Jonge, M.D., Punshon, T., Jackson, B.P., Guerinot, M.L., Price, A.H., Meharg, A.A., 2012. A review of recent developments in the speciation and location of arsenic and selenium in rice grain. Anal. Bioanal. Chem. 402, 3275-3286.

Carey, A.-M., Scheckel, K.G., Lombi, E., Newville, M., Choi, Y., Norton, G.J., Charnock, J.M., Feldmann, J., Price, A.H., Meharg, A.A., 2010. Grain unloading of arsenic species in rice. Plant Physiol. 152, 309-319.

Chao, D.-Y., Chen, Y., Chen, J., Shi, S., Chen, Z., Wang, C., Danku, J.M., Zhao, F.-J., Salt, D.E., 2014. Genome-wide association mapping identifies a new arsenate reductase enzyme critical for limiting arsenic accumulation in plants. PLOS Biol. 12, 1-17.

Chen, H.-L., Lee, C.-C., Huang, W.-J., Huang, H.-T., Wu, Y.-C., Hsu, Y.-C., Kao, Y.-T., 2016a. Arsenic speciation in rice and risk assessment of inorganic arsenic in Taiwan population. Environ. Sci. Pollut. Res. 23, 4481-4488. 
Chen, W.-Q., Shi, Y.-L., Wu, S.-L., Zhu, Y.-G., 2016b. Anthropogenic arsenic cycles: a research framework and features. J. Clean. Prod. 139, 328-336.

Chen, Y., Han, Y.-H., Cao, Y., Zhu, Y.-G., Rathinasabapathi, B., Ma, L.Q., 2017a. Arsenic transport in rice and biological solutions to reduce arsenic risk from rice. Front. Plant Sci. 8.

Chen, Y., Sun, S.-K., Tang, Z., Liu, G., Moore, K.L., Maathuis, F.J., Miller, A.J., McGrath, S.P., Zhao, F.-J., 2017b. The Nodulin 26-like intrinsic membrane protein OsNIP3; 2 is involved in arsenite uptake by lateral roots in rice. J. Exp. Bot., 1-10.

Chou, M.-L., Jean, J.-S., Sun, G.-X., Hseu, Z.-Y., Yang, C.-M., Das, S., Teng, J.-H., 2014. Distribution and accumulation of arsenic in rice plants grown in arsenic-rich agricultural soil. Agron. J. 106, 945-951.

Das, S., Chou, M.-L., Jean, J.-S., Liu, C.-C., Yang, H.-J., 2016. Water management impacts on arsenic behavior and rhizosphere bacterial communities and activities in a rice agroecosystem. Sci. Total Environ. 542, 642-652.

Dittmar, J., Voegelin, A., Maurer, F., Roberts, L.C., Hug, S.J., Saha, G.C., Ali, M.A., Badruzzaman, A.B.M., Kretzschmar, R., 2010. Arsenic in soil and irrigation water affects arsenic uptake by rice: complementary insights from field and pot studies. Environ. Sci. Technol. 44, 8842-8848.

DiTusa, S.F., Fontenot, E.B., Wallace, R.W., Silvers, M.A., Steele, T.N., Elnagar, A.H., Dearman, K.M., Smith, A.P., 2016. A member of the Phosphate transporter 1 (Pht1) family from the arsenic-hyperaccumulating fern Pteris vittata is a high-affinity arsenate transporter. New Phytol. 209, 762-772.

Duan, G.-L., Hu, Y., Liu, W.-J., Kneer, R., Zhao, F.-J., Zhu, Y.-G., 2011. Evidence for a role of phytochelatins in regulating arsenic accumulation in rice grain. Environ. Exp. Bot. 71, 416-421. 
Duan, G.-L., Hu, Y., Schneider, S., McDermott, J., Chen, J., Sauer, N., Rosen, B.P., Daus, B., Liu, Z., Zhu, Y.-G., 2016. Inositol transporters AtINT2 and AtINT4 regulate arsenic accumulation in Arabidopsis seeds. Nat. Plants 2, 15202.

Dwivedi, S., Tripathi, R., Tripathi, P., Kumar, A., Dave, R., Mishra, S., Singh, R., Sharma, D., Rai, U., Chakrabarty, D., 2010. Arsenate exposure affects amino acids, mineral nutrient status and antioxidants in rice (Oryza sativa L.) genotypes. Environ. Sci. Technol. 44, 9542-9549.

Farrow, E.M., Wang, J., Burken, J.G., Shi, H., Yan, W., Yang, J., Hua, B., Deng, B., 2015. Reducing arsenic accumulation in rice grain through iron oxide amendment. Ecotox. Environ. Safe. 118, 55-61.

Finnegan, P., Chen, W., 2012. Arsenic toxicity: the effects on plant metabolism. Front. Physiol. 3, 182.

Fleck, A.T., Mattusch, J., Schenk, M.K., 2013. Silicon decreases the arsenic level in rice grain by limiting arsenite transport. J. Plant Nutr. Soil Sc. 176, 785-794.

Fontenot, E.B., Ditusa, S.F., Kato, N., Olivier, D.M., Dale, R., Lin, W.Y., Chiou, T.J., Macnaughtan, M.A., Smith, A.P., 2015. Increased phosphate transport of Arabidopsis thaliana Pht1; 1 by site-directed mutagenesis of tyrosine 312 may be attributed to the disruption of homomeric interactions. Plant Cell Environ. 38, 2012-2022.

Fu, Y., Chen, M., Bi, X., He, Y., Ren, L., Xiang, W., Qiao, S., Yan, S., Li, Z., Ma, Z., 2011. Occurrence of arsenic in brown rice and its relationship to soil properties from Hainan Island, China. Environ. Pollut. 159, 1757-1762.

Geng, A., Wang, X., Wu, L., Wang, F., Chen, Y., Yang, H., Zhang, Z., Zhao, X., 2017. Arsenic accumulation and speciation in rice grown in arsanilic acid-elevated paddy soil. Ecotox. Environ. Safe. 137, 172-178. 
Geng, C.-N., Zhu, Y.-G., Liu, W.-J., Smith, S.E., 2005. Arsenate uptake and translocation in seedlings of two genotypes of rice is affected by external phosphate concentrations. Aquatic Botany 83, 321-331.

Guo, W., Zhang, J., Teng, M., Wang, L.H., 2009. Arsenic uptake is suppressed in a rice mutant defective in silicon uptake. J. Plant Nutr. Soil Sc. 172, 867-874.

Guo, W., Zhu, Y.-G., Liu, W.-J., Liang, Y.-C., Geng, C.-N., Wang, S.-G., 2007. Is the effect of silicon on rice uptake of arsenate (As V) related to internal silicon concentrations, iron plaque and phosphate nutrition? Environ. Pollut. 148, 251-257.

Halder, D., Biswas, A., Šlejkovec, Z., Chatterjee, D., Nriagu, J., Jacks, G., Bhattacharya, P., 2014. Arsenic species in raw and cooked rice: implications for human health in rural Bengal. Sci. Total Environ. 497, 200-208.

Hayat, K., Menhas, S., Bundschuh, J., Chaudhary, H.J., 2017. Microbial biotechnology as an emerging industrial wastewater treatment process for arsenic mitigation: a critical review. J. Clean. Prod. 151, 427-438.

He, Z., Yan, H., Chen, Y., Shen, H., Xu, W., Zhang, H., Shi, L., Zhu, Y.G., Ma, M., 2016. An aquaporin PvTIP4; 1 from Pteris vittata may mediate arsenite uptake. New Phytol. 209, 746-761.

Heitkemper, D., Kubachka, K., Halpin, P., Allen, M., Shockey, N., 2009. Survey of total arsenic and arsenic speciation in US-produced rice as a reference point for evaluating change and future trends. Food Addit. Contam. 2, 112-120.

Herath, I., Vithanage, M., Bundschuh, J., Maity, J.P., Bhattacharya, P., 2016. Natural arsenic in global groundwaters: distribution and geochemical triggers for mobilization. Curr. Pollut. Report. 2, 68-89. 
Honma, T., Ohba, H., Kaneko-Kadokura, A., Makino, T., Nakamura, K., Katou, H., 2016. Optimal soil Eh, $\mathrm{pH}$, and water management for simultaneously minimizing arsenic and cadmium concentrations in rice grains. Environ. Sci. Technol. 50, 4178-4185.

Hossain, M., Jahiruddin, M., Panaullah, G., Loeppert, R., Islam, M., Duxbury, J., 2008. Spatial variability of arsenic concentration in soils and plants, and its relationship with iron, manganese and phosphorus. Environ. Pollut. 156, 739-744.

Hsu, W.-M., Hsi, H.-C., Huang, Y.-T., Liao, C.-S., Hseu, Z.-Y., 2012. Partitioning of arsenic in soil-crop systems irrigated using groundwater: a case study of rice paddy soils in southwestern Taiwan. Chemosphere 86, 606-613.

Jia, Y., Huang, H., Sun, G.-X., Zhao, F.-J., Zhu, Y.-G., 2012. Pathways and relative contributions to arsenic volatilization from rice plants and paddy soil. Environ. Sci. Technol. 46, 8090-8096.

Jiang, J., Bauer, I., Paul, A., Kappler, A., 2009. Arsenic redox changes by microbially and chemically formed semiquinone radicals and hydroquinones in a humic substance model quinone. Environ. Sci. Technol. 43, 3639-3645.

Jiang, W., Hou, Q., Yang, Z., Zhong, C., Zheng, G., Yang, Z., Li, J., 2014. Evaluation of potential effects of soil available phosphorus on soil arsenic availability and paddy rice inorganic arsenic content. Environ. Pollut. 188, 159-165.

Juskelis, R., Li, W., Nelson, J., Cappozzo, J.C., 2013. Arsenic speciation in rice cereals for infants. J. Agri. Food Chem. 61, 10670-10676.

Kamiya, T., Fujiwara, T., 2009. Arabidopsis NIP1; 1 transports antimonite and determines antimonite sensitivity. Plant Cell Physiol. 50, 1977-1981.

Kamiya, T., Islam, R., Duan, G., Uraguchi, S., Fujiwara, T., 2013. Phosphate deficiency signaling pathway is a target of arsenate and phosphate transporter OsPT1 is involved in As accumulation in shoots of rice. Soil Sci. Plant Nutr. 59, 580-590. 
Katsuhara, M., Sasano, S., Horie, T., Matsumoto, T., Rhee, J., Shibasaka, M., 2014. Functional and molecular characteristics of rice and barley NIP aquaporins transporting water, hydrogen peroxide and arsenite. Plant Biotechnol. 31, 213-219.

Khan, M.A., Islam, M.R., Panaullah, G., Duxbury, J.M., Jahiruddin, M., Loeppert, R.H., 2010a. Accumulation of arsenic in soil and rice under wetland condition in Bangladesh. Plant Soil 333, 263-274.

Khan, M.A., Stroud, J.L., Zhu, Y.-G., McGrath, S.P., Zhao, F.-J., 2010b. Arsenic bioavailability to rice is elevated in Bangladeshi paddy soils. Environ. Sci. Technol. 44, $8515-8521$.

Kile, M.L., Houseman, E.A., Breton, C.V., Smith, T., Quamruzzaman, Q., Rahman, M., Mahiuddin, G., Christiani, D.C., 2007. Dietary arsenic exposure in Bangladesh. Environ. Heal. Persp., 889-893.

Kim, J.-Y., Kim, W.-I., Kunhikrishnan, A., Kang, D.-W., Kim, D.-H., Lee, Y.-J., Kim, Y.-J., Kim, C.-T., 2013. Determination of arsenic species in rice grains using HPLC-ICP-MS. Food Sci. Biotechnol. 22, 1509-1513.

Kuramata, M., Abe, T., Matsumoto, S., Ishikawa, S., 2011. Arsenic accumulation and speciation in Japanese paddy rice cultivars. Soil Sci. Plant Nutr. 57, 248-258.

Laborte, A.G., Gutierrez, M.A., Balanza, J.G., Saito, K., Zwart, S.J., Boschetti, M., Murty, M., Villano, L., Aunario, J.K., Reinke, R., 2017. RiceAtlas, a spatial database of global rice calendars and production. Sci. Data 4.

Lafferty, B.J., Ginder-Vogel, M., Sparks, D.L., 2011. Arsenite oxidation by a poorlycrystalline manganese oxide. 3. arsenic and manganese desorption. Environ. Sci. Technol. 45, 9218-9223.

Lee, C.-H., Hsieh, Y.-C., Lin, T.-H., Lee, D.-Y., 2013. Iron plaque formation and its effect on arsenic uptake by different genotypes of paddy rice. Plant Soil 363, 231-241. 
Lei, M., Tie, B., Zeng, M., Qing, P., Song, Z., Williams, P.N., Huang, Y., 2013. An arseniccontaminated field trial to assess the uptake and translocation of arsenic by genotypes of rice. Environ. Geochem. Heal. 35, 379-390.

Li, R.-Y., Ago, Y., Liu, W.-J., Mitani, N., Feldmann, J., McGrath, S.P., Ma, J.F., Zhao, F.-J., 2009. The rice aquaporin Lsil mediates uptake of methylated arsenic species. Plant Physiol. 150, 2071-2080.

Li, R., Zhou, Z., Zhang, Y., Xie, X., Li, Y., Shen, X., 2015. Uptake and accumulation characteristics of arsenic and iron plaque in rice at different growth stages. Commun. Soil Sci. Plan. 46, 2509-2522.

Li, X., Yan, W., Agrama, H., Jackson, A., Jia, M., Jia, L., Moldenhauer, K., Correa, F., Wu, D., 2016. Genetic analysis of genetic basis of a physiological disorder "straighthead" in rice (Oryza sativa L.). Genes Genom. 38, 453-457.

Li, Y., Yu, S., Strong, J., Wang, H., 2012. Are the biogeochemical cycles of carbon, nitrogen, sulfur, and phosphorus driven by the "Fe III-Fe II redox wheel" in dynamic redox environments? J. Soil. Sediment. 12, 683-693.

Liang, Y., Hua, H., Zhu, Y.G., Zhang, J., Cheng, C., Römheld, V., 2006. Importance of plant species and external silicon concentration to active silicon uptake and transport. New Phytol. 172, 63-72.

Lihong, W., Guilan, D., 2009. Effect of external and internal phosphate status on arsenic toxicity and accumulation in rice seedlings. J. Environ. Sci. 21, 346-351.

Liu, C., Yu, H.-Y., Liu, C., Li, F., Xu, X., Wang, Q., 2015. Arsenic availability in rice from a mining area: is amorphous iron oxide-bound arsenic a source or sink? Environmental Pollution 199, 95-101. 
Liu, W., Zhu, Y., Hu, Y., Williams, P., Gault, A., Meharg, A., Charnock, J., Smith, F., 2006. Arsenic sequestration in iron plaque, its accumulation and speciation in mature rice plants (Oryza sativa L.). Environ. Sci. Technol. 40, 5730-5736.

Liu, W., Zhu, Y., Smith, F., Smith, S., 2004. Do iron plaque and genotypes affect arsenate uptake and translocation by rice seedlings (Oryza sativa L.) grown in solution culture? J. Exp. Bot. 55, 1707-1713.

Ma, J.F., Yamaji, N., Mitani, N., Tamai, K., Konishi, S., Fujiwara, T., Katsuhara, M., Yano, M., 2007. An efflux transporter of silicon in rice. Nature 448, 209.

Ma, J.F., Yamaji, N., Mitani, N., Xu, X.-Y., Su, Y.-H., McGrath, S.P., Zhao, F.-J., 2008. Transporters of arsenite in rice and their role in arsenic accumulation in rice grain. Proc. Natl. Acad. Sci. 105, 9931-9935.

Ma, L., Wang, L., Jia, Y., Yang, Z., 2016. Arsenic speciation in locally grown rice grains from Hunan province, China: spatial distribution and potential health risk. Sci. Total Environ. 557, 438-444.

Majzlan, J., Drahota, P., Filippi, M., 2014. Parageneses and crystal chemistry of arsenic minerals. Rev. Mineral. Geochem. 79, 17-184.

Malasarn, D., Saltikov, C., Campbell, K., Santini, J., Hering, J., Newman, D., 2004. arrA is a reliable marker for As(V) respiration. Science 306, 455-455.

Meharg, A.A., Sun, G., Williams, P.N., Adomako, E., Deacon, C., Zhu, Y.-G., Feldmann, J., Raab, A., 2008. Inorganic arsenic levels in baby rice are of concern. Environ. Pollut. 152, 746-749.

Meharg, A.A., Williams, P.N., Adomako, E., Lawgali, Y.Y., Deacon, C., Villada, A., Cambell, R.C., Sun, G., Zhu, Y.-G., Feldmann, J., 2009. Geographical variation in total and inorganic arsenic content of polished (white) rice. Environmen. Sci. Technol. 43, 1612-1617. 
Meharg, C., Meharg, A.A., 2015. Silicon, the silver bullet for mitigating biotic and abiotic stress, and improving grain quality, in rice? Environ. Exp. Bot. 120, 8-17.

Mei, X., Ye, Z., Wong, M., 2009. The relationship of root porosity and radial oxygen loss on arsenic tolerance and uptake in rice grains and straw. Environ. Pollut. 157, 2550-2557.

Meng, X.Y., Qin, J., Wang, L.H., Duan, G.L., Sun, G.X., Wu, H.L., Chu, C.C., Ling, H.Q., Rosen, B.P., Zhu, Y.G., 2011. Arsenic biotransformation and volatilization in transgenic rice. New Phytol. 191, 49-56.

Mihucz, V.G., Tatár, E., Virág, I., Cseh, E., Fodor, F., Záray, G., 2005. Arsenic speciation in xylem sap of cucumber (Cucumis sativus L.). Anal. Bioanal. Chem. 383, 461-466.

Mishra, S., Mattusch, J., Wennrich, R., 2017. Accumulation and transformation of inorganic and organic arsenic in rice and role of thiol-complexation to restrict their translocation to shoot. Sci. Rep. 7.

Mladenov, N., Zheng, Y., Simone, B., Bilinski, T.M., McKnight, D.M., Nemergut, D., Radloff, K.A., Rahman, M.M., Ahmed, K.M., 2015. Dissolved organic matter quality in a shallow aquifer of Bangladesh: implications for arsenic mobility. Environ. Sci. Technol. 49, 10815-10824.

Mondal, D., Polya, D.A., 2008. Rice is a major exposure route for arsenic in Chakdaha block, Nadia district, West Bengal, India: a probabilistic risk assessment. Appl. Geochem. 23, 2987-2998

Mosa, K.A., Kumar, K., Chhikara, S., Mcdermott, J., Liu, Z., Musante, C., White, J.C., Dhankher, O.P., 2012. Members of rice plasma membrane intrinsic proteins subfamily are involved in arsenite permeability and tolerance in plants. Transgenic Res. 21, 1265-1277.

Muehe, E.M., Eisele, J.F., Daus, B., Kappler, A., Harter, K., Chaban, C., 2014. Are rice (Oryza sativa L.) phosphate transporters regulated similarly by phosphate and arsenate? a comprehensive study. Plant Mol. Biol. 85, 301-316. 
Newman, D.K., Kolter, R., 2000. A role for excreted quinones in extracellular electron transfer. Nature 405, 94.

Nookabkaew, S., Rangkadilok, N., Mahidol, C., Promsuk, G., Satayavivad, J., 2013. Determination of arsenic species in rice from Thailand and other Asian countries using simple extraction and HPLC-ICP-MS analysis. J. Agri. Food Chem. 61, 6991-6998.

Norton, G.J., Duan, G., Dasgupta, T., Islam, M.R., Lei, M., Zhu, Y., Deacon, C.M., Moran, A.C., Islam, S., Zhao, F.-J., 2009. Environmental and genetic control of arsenic accumulation and speciation in rice grain: comparing a range of common cultivars grown in contaminated sites across Bangladesh, China, and India. Environ. Sci. Technol. 43, $8381-8386$

Ohno, K., Yanase, T., Matsuo, Y., Kimura, T., Rahman, M.H., Magara, Y., Matsui, Y., 2007. Arsenic intake via water and food by a population living in an arsenic-affected area of Bangladesh. Sci. Total Environ. 381, 68-76.

Pan, Y., Koopmans, G.F., Bonten, L.T., Song, J., Luo, Y., Temminghoff, E.J., Comans, R.N., 2014. Influence of $\mathrm{pH}$ on the redox chemistry of metal (hydr)oxides and organic matter in paddy soils. J. Soil. Sediment. 14, 1713-1726.

Qiao, J.-t., Li, X.-m., Hu, M., Li, F.-b., Young, L.Y., Sun, W.-m., Huang, W., Cui, J.-h., 2017. Transcriptional activity of arsenic-reducing bacteria and genes regulated by lactate and biochar during arsenic transformation in flooded paddy soil. Environ. Sci. Technol. $52,61-70$.

Qiao, J.-t., Li, X.-m., Li, F.-b., 2018. Roles of different active metal-reducing bacteria in arsenic release from arsenic-contaminated paddy soil amended with biochar. J. Hazard. Mater. 344, 958-967.

Raab, A., Williams, P.N., Meharg, A., Feldmann, J., 2007. Uptake and translocation of inorganic and methylated arsenic species by plants. Environ. Chem. 4, 197-203. 
Rahman, M.A., Hasegawa, H., Rahman, M.M., Islam, M.N., Miah, M.M., Tasmen, A., 2007a. Effect of arsenic on photosynthesis, growth and yield of five widely cultivated rice (Oryza sativa L.) varieties in Bangladesh. Chemosphere 67, 1072-1079.

Rahman, M.A., Hasegawa, H., Rahman, M.M., Rahman, M.A., Miah, M., 2007b. Accumulation of arsenic in tissues of rice plant (Oryza sativa L.) and its distribution in fractions of rice grain. Chemosphere 69, 942-948.

Rahman, M.A., Rahman, M.M., Reichman, S.M., Lim, R.P., Naidu, R., 2014. Arsenic speciation in Australian-grown and imported rice on sale in Australia: implications for human health risk. J. Agri. Food Chem. 62, 6016-6024.

Rahman, M.M., Asaduzzaman, M., Naidu, R., 2013. Consumption of arsenic and other elements from vegetables and drinking water from an arsenic-contaminated area of Bangladesh. J. Hazard. Mater. 262, 1056-1063.

Rahman, M.S., Abdul Mazid Miah, M., Khaled, H.M., Islam, A., Panaullah, G., 2010. Arsenic concentrations in groundwater, soils, and irrigated rice in Southwestern Bangladesh. Commun. Soil Sci. Plan. 41, 1889-1895.

Sahrawat, K.L., 2015. Redox potential and $\mathrm{pH}$ as major drivers of fertility in submerged rice soils: a conceptual framework for management. Commun. Soil Sci. Plan. 46, 1597-1606.

Sandhi, A., Greger, M., Landberg, T., Jacks, G., Bhattacharya, P., 2017. Arsenic concentrations in local aromatic and high-yielding hybrid rice cultivars and the potential health risk: a study in an arsenic hotspot. Environ. Monit. Assess. 189, 184.

Seyfferth, A.L., Fendorf, S., 2012. Silicate mineral impacts on the uptake and storage of arsenic and plant nutrients in rice (Oryza sativa L.). Environ. Sci. Technol. 46, 1317613183. 
Seyfferth, A.L., McCurdy, S., Schaefer, M.V., Fendorf, S., 2014. Arsenic concentrations in paddy soil and rice and health implications for major rice-growing regions of Cambodia. Environ. Sci. Technol. 48, 4699-4706.

Seyfferth, A.L., Webb, S.M., Andrews, J.C., Fendorf, S., 2011. Defining the distribution of arsenic species and plant nutrients in rice (Oryza sativa L.) from the root to the grain. Geochim. Cosmochim. Ac. 75, 6655-6671.

Shi, S., Wang, T., Chen, Z., Tang, Z., Wu, Z., Salt, D.E., Chao, D.-Y., Zhao, F., 2016a. OsHAC1;1 and OsHAC1;2 function as arsenate reductases and regulate arsenic accumulation. Plant Physiol.

Shi, S., Wang, T., Chen, Z., Tang, Z., Wu, Z., Salt, D.E., Chao, D.-Y., Zhao, F., 2016b. OsHAC1; 1 and OsHAC1; 2 function as arsenate reductases and regulate arsenic accumulation. Plant Physiol., pp. 01332.02016.

Shin, H., Shin, H.S., Dewbre, G.R., Harrison, M.J., 2004. Phosphate transport in Arabidopsis: Pht1; 1 and Pht1; 4 play a major role in phosphate acquisition from both low-and highphosphate environments. Plant J. 39, 629-642.

Shrestha, J., Rich, J.J., Ehrenfeld, J.G., Jaffe, P.R., 2009. Oxidation of ammonium to nitrite under iron-reducing conditions in wetland soils: Laboratory, field demonstrations, and push-pull rate determination. Soil Sci. 174, 156-164.

Shri, M., Dave, R., Diwedi, S., Shukla, D., Kesari, R., Tripathi, R.D., Trivedi, P.K., Chakrabarty, D., 2014. Heterologous expression of Ceratophyllum demersum phytochelatin synthase, CdPCS1, in rice leads to lower arsenic accumulation in grain. Sci. Rep. 4.

Shrivastava, A., Barla, A., Singh, S., Mandraha, S., Bose, S., 2017. Arsenic contamination in agricultural soils of Bengal deltaic region of West Bengal and its higher assimilation in monsoon rice. J. Hazard. Mater. 324, 526-534. 
Signes-Pastor, A.J., Carey, M., Meharg, A.A., 2016. Inorganic arsenic in rice-based products for infants and young children. Food Chem. 191, 128-134.

Smith, E., Juhasz, A., Weber, J., Naidu, R., 2008. Arsenic uptake and speciation in rice plants grown under greenhouse conditions with arsenic contaminated irrigation water. Sci. Total Environ. 392, 277-283.

Sommella, A., Deacon, C., Norton, G., Pigna, M., Violante, A., Meharg, A.A., 2013. Total arsenic, inorganic arsenic, and other elements concentrations in Italian rice grain varies with origin and type. Environ. Pollut. 181, 38-43.

Song, W.-Y., Park, J., Mendoza-Cózatl, D.G., Suter-Grotemeyer, M., Shim, D., Hörtensteiner, S., Geisler, M., Weder, B., Rea, P.A., Rentsch, D., 2010. Arsenic tolerance in Arabidopsis is mediated by two ABCC-type phytochelatin transporters. Proc. Natl. Acad. Sci. 107, 21187-21192.

Song, W.-Y., Yamaki, T., Yamaji, N., Ko, D., Jung, K.-H., Fujii-Kashino, M., An, G., Martinoia, E., Lee, Y., Ma, J.F., 2014. A rice ABC transporter, OsABCC1, reduces arsenic accumulation in the grain. Proc. Natl. Acad. Sci. 111, 15699-15704.

Spanu, A., Daga, L., Orlandoni, A.M., Sanna, G., 2012. The role of irrigation techniques in arsenic bioaccumulation in rice (Oryza sativa L.). Environ. Sci. Technol. 46, 8333-8340.

Su, Y.H., McGrath, S.P., Zhu, Y.G., Zhao, F.J., 2008. Highly efficient xylem transport of arsenite in the arsenic hyperaccumulator Pteris vittata. New Phytol. 180, 434-441.

Sun, G.-X., Williams, P.N., Zhu, Y.-G., Deacon, C., Carey, A.-M., Raab, A., Feldmann, J., Meharg, A.A., 2009a. Survey of arsenic and its speciation in rice products such as breakfast cereals, rice crackers and Japanese rice condiments. Environ. Int. 35, 473-475.

Sun, W., Sierra-Alvarez, R., Milner, L., Oremland, R., Field, J.A., 2009b. Arsenite and ferrous iron oxidation linked to chemolithotrophic denitrification for the immobilization of arsenic in anoxic environments. Environ. Sci. Technol. 43, 6585-6591. 
Syu, C.-H., Huang, C.-C., Jiang, P.-Y., Lee, C.-H., Lee, D.-Y., 2015. Arsenic accumulation and speciation in rice grains influenced by arsenic phytotoxicity and rice genotypes grown in arsenic-elevated paddy soils. J. Hazard. Mater. 286, 179-186.

Tang, Z., Chen, Y., Chen, F., Ji, Y., Zhao, F.-J., 2017. OsPTR7 (OsNPF8. 1), a putative peptide transporter in rice, is involved in dimethylarsenate accumulation in rice grain. Plant Cell Physiol. 58, 904-913.

Tenni, D., Martin, M., Barberis, E., Beone, G.M., Miniotti, E., Sodano, M., Zanzo, E., Fontanella, M.C., Romani, M., 2017. Total As and As speciation in Italian rice as related to producing areas and paddy soils properties. J. Agri. Food Chem. 65, 3443-3452.

Tiwari, M., Sharma, D., Dwivedi, S., Singh, M., Tripathi, R.D., Trivedi, P.K., 2014. Expression in Arabidopsis and cellular localization reveal involvement of rice NRAMP, OsNRAMP1, in arsenic transport and tolerance. Plant Cell Environ. 37, 140-152.

Vicky-Singh, Brar, M., Preeti-Sharma, Malhi, S., 2010. Arsenic in water, soil, and rice plants in the Indo-Gangetic plains of northwestern India. Commun. Soil Sci. Plan. 41, 13501360.

Villegas-Torres, M.F., Bedoya-Reina, O.C., Salazar, C., Vives-Florez, M.J., Dussan, J., 2011. Horizontal arsC gene transfer among microorganisms isolated from arsenic polluted soil. Int. Biodeter. Biodegr. 65, 147-152.

Wang, H.-Y., Wen, S.-L., Chen, P., Zhang, L., Cen, K., Sun, G.-X., 2016a. Mitigation of cadmium and arsenic in rice grain by applying different silicon fertilizers in contaminated fields. Environ. Sci. Pollut. Res. 23, 3781-3788.

Wang, P., Zhang, W., Mao, C., Xu, G., Zhao, F.-J., 2016b. The role of OsPT8 in arsenate uptake and varietal difference in arsenate tolerance in rice. J. Exp. Bot. 67, 6051-6059. 
Williams, P., Price, A., Raab, A., Hossain, S., Feldmann, J., Meharg, A., 2005. Variation in arsenic speciation and concentration in paddy rice related to dietary exposure. Environ. Sci. Technol. 39, 5531-5540.

Williams, P.N., Islam, S., Islam, R., Jahiruddin, M., Adomako, E., Soliaman, A., Rahman, G., Lu, Y., Deacon, C., Zhu, Y.-G., 2009a. Arsenic limits trace mineral nutrition (selenium, zinc, and nickel) in Bangladesh rice grain. Environ. Sci. Technol. 43, 8430-8436.

Williams, P.N., Lei, M., Sun, G., Huang, Q., Lu, Y., Deacon, C., Meharg, A.A., Zhu, Y.-G., 2009b. Occurrence and partitioning of cadmium, arsenic and lead in mine impacted paddy rice: Hunan, China. Environ. Sci. Technol. 43, 637-642.

Williams, P.N., Villada, A., Deacon, C., Raab, A., Figuerola, J., Green, A.J., Feldmann, J., Meharg, A.A., 2007. Greatly enhanced arsenic shoot assimilation in rice leads to elevated grain levels compared to wheat and barley. Environ. Sci. Technol. 41, 6854-6859.

Williams, P.N., Zhang, H., Davison, W., Meharg, A.A., Hossain, M., Norton, G.J., Brammer, H., Islam, M.R., 2011. Organic matter - solid phase interactions are critical for predicting arsenic release and plant uptake in Bangladesh paddy soils. Environ. Sci. Technol. 45, 6080-6087.

Wu, C., Huang, L., Xue, S.-G., Pan, W.-S., Zou, Q., Hartley, W., Wong, M.-H., 2017. Oxic and anoxic conditions affect arsenic (As) accumulation and arsenite transporter expression in rice. Chemosphere 168, 969-975.

Wu, C., Ye, Z., Shu, W., Zhu, Y., Wong, M., 2011a. Arsenic accumulation and speciation in rice are affected by root aeration and variation of genotypes. J. Exp. Bot. 62, 2889-2898.

Wu, Z., Ren, H., McGrath, S.P., Wu, P., Zhao, F.-J., 2011b. Investigating the contribution of the phosphate transport pathway to arsenic accumulation in rice. Plant Physiol. 157, 498508. 
Xu, J., Shi, S., Wang, L., Tang, Z., Lv, T., Zhu, X., Ding, X., Wang, Y., Zhao, F.J., Wu, Z., 2017a. OsHAC4 is critical for arsenate tolerance and regulates arsenic accumulation in rice. New Phytol. 215, 1090-1101.

Xu, W., Dai, W., Yan, H., Li, S., Shen, H., Chen, Y., Xu, H., Sun, Y., He, Z., Ma, M., 2015. Arabidopsis NIP3; 1 plays an important role in arsenic uptake and root-to-shoot translocation under arsenite stress conditions. Mol. Plant 8, 722-733.

Xu, X., Chen, C., Wang, P., Kretzschmar, R., Zhao, F.-J., 2017b. Control of arsenic mobilization in paddy soils by manganese and iron oxides. Environ. Pollut. 231, 37-47.

Xu, X., McGrath, S., Meharg, A., Zhao, F., 2008. Growing rice aerobically markedly decreases arsenic accumulation. Environ. Sci. Technol. 42, 5574-5579.

Xu, X., McGrath, S., Zhao, F., 2007. Rapid reduction of arsenate in the medium mediated by plant roots. New Phytol. 176, 590-599.

Yamaguchi, N., Ohkura, T., Takahashi, Y., Maejima, Y., Arao, T., 2014. Arsenic distribution and speciation near rice roots influenced by iron plaques and redox conditions of the soil matrix. Environ. Sci. Technol. 48, 1549-1556.

Yang, T., Zhang, S., Hu, Y., Wu, F., Hu, Q., Chen, G., Cai, J., Wu, T., Moran, N., Yu, L., 2014. The role of a potassium transporter OsHAK5 in potassium acquisition and transport from roots to shoots in rice at low potassium supply levels. Plant Physiol. 166, 945-959.

Ye, W., Fan, T., Lu, H., Zhang, G., Chen, H., Zhang, J., Hua, R., 2015. Arsenic speciation in xylem exudates of rice growing in arsenic-contaminated soil. Acta Agri. Scand. B-S P. 65, $697-701$.

Ye, W., Zhang, J., Fan, T., Lu, H., Chen, H., Li, X., Hua, R., 2017. Arsenic speciation in the phloem exudates of rice and its role in arsenic accumulation in rice grains. Ecotox. Environ. Safe. 143, 87-91. 
Yu, H.-Y., Ding, X., Li, F., Wang, X., Zhang, S., Yi, J., Liu, C., Xu, X., Wang, Q., 2016a. The availabilities of arsenic and cadmium in rice paddy fields from a mining area: the role of soil extractable and plant silicon. Environ. Pollut. 215, 258-265.

Yu, H.-Y., Li, F.-B., Liu, C.-S., Huang, W., Liu, T.-X., Yu, W.-M., 2016b. Iron redox cycling coupled to transformation and immobilization of heavy metals: implications for paddy rice safety in the red soil of South China. Adv. Agron. 137, 279-317.

Yu, H.-Y., Wang, X., Li, F., Li, B., Liu, C., Wang, Q., Lei, J., 2017. Arsenic mobility and bioavailability in paddy soil under iron compound amendments at different growth stages of rice. Environ. Pollut. 224, 136-147.

Zhang, J., Zhao, Q.-Z., Duan, G.-L., Huang, Y.-C., 2011. Influence of sulphur on arsenic accumulation and metabolism in rice seedlings. Environ. Exp. Bot. 72, 34-40.

Zhang, J., Zhou, W., Liu, B., He, J., Shen, Q., Zhao, F.-J., 2015. Anaerobic arsenite oxidation by an autotrophic arsenite-oxidizing bacterium from an arsenic-contaminated paddy soil. Environ. Sci. Technol. 49, 5956-5964.

Zhao, F.-J., Harris, E., Yan, J., Ma, J., Wu, L., Liu, W., McGrath, S.P., Zhou, J., Zhu, Y.-G., 2013a. Arsenic methylation in soils and its relationship with microbial arsM abundance and diversity, and As speciation in rice. Environ. Sci. Technol. 47, 7147-7154.

Zhao, F.-J., McGrath, S.P., Meharg, A.A., 2010a. Arsenic as a food chain contaminant: mechanisms of plant uptake and metabolism and mitigation strategies. Annu. Rev. Plant Biol. 61, 535-559.

Zhao, F.-J., Stroud, J.L., Khan, M.A., McGrath, S.P., 2012. Arsenic translocation in rice investigated using radioactive ${ }^{73}$ As tracer. Plant Soil 350, 413-420.

Zhao, F.-J., Zhu, Y.-G., Meharg, A.A., 2013b. Methylated arsenic species in rice: geographical variation, origin, and uptake mechanisms. Environ. Sci. Technol. 47, 39573966. 
Zhao, F., Ma, J., Meharg, A., McGrath, S., 2009. Arsenic uptake and metabolism in plants. New Phytol. 181, 777-794.

Zhao, F.J., Ago, Y., Mitani, N., Li, R.Y., Su, Y.H., Yamaji, N., McGrath, S.P., Ma, J.F., 2010b. The role of the rice aquaporin Lsi1 in arsenite efflux from roots. New Phytol. 186, 392-399.

Zheng, M.Z., Cai, C., Hu, Y., Sun, G.X., Williams, P.N., Cui, H.J., Li, G., Zhao, F.J., Zhu, Y.G., 2011. Spatial distribution of arsenic and temporal variation of its concentration in rice. New Phytol. 189, 200-209.

Zhu, Y.-G., Sun, G.-X., Lei, M., Teng, M., Liu, Y.-X., Chen, N.-C., Wang, L.-H., Carey, A., Deacon, C., Raab, A., 2008. High percentage inorganic arsenic content of mining impacted and nonimpacted Chinese rice. Environ. Sci. Technol. 42, 5008-5013. 


\section{Table captions}

\section{Table 1}

Key representative genes involved in As uptake, transport, and metabolism in rice plants.

\section{Table 2}

Arsenic concentration in irrigation water, soil and different plant tissues worldwide from field experiments.

\section{Table 3}

Arsenic speciation in different rice tissues from glasshouse experiments.

\section{Table 4}

Arsenic speciation in market-based rice in different countries. 
Table 1

Key representative genes involved in As uptake, transport, and metabolism in rice plants.

Function

Gene category

Phosphate transporters

phloem, and grain

As(III) uptake by root
Gene name

OsPHT1;8 (OsPT8)

OsPHT $1 ; 1$

OsNIP2;1 (Lsi1)

OsNIP2;2 (Lsi2)

OsNIP $1 ; 1$

OsNIP3;1

OsNIP3;2

OsNIP $3 ; 3$

Plasma membrane intrinsic proteins (PIPs)
OsPIP2;4

OsPIP2;6

\section{Reference}

Wang et al. (2016b)

Kamiya et al. (2013)

Ma et al. (2008)

Chen et al. (2017a)

Katsuhara et al. (2014) 
DMA(V) and MMA(V) uptake by root

$\mathrm{As}(\mathrm{V})$ reduction to $\mathrm{As}(\mathrm{III})$ in root

As(V) reductase

As(III) efflux from root to the external Nodulin 26-like intrinsic proteins (NIPs)

environment

As(III) complexation in root and phloem

ATP-binding cassette transporter

DMA(V)loading into the xylem, phloem, Putative peptide transporter

leaves, and grain

As(III) loading into the xylem
Natural Resistance-Associated Macrophage OsNRAMP1

Protein (NRAMP) transporter
OsHAC1;1

OsHAC $1 ; 2$

OsHAC4

OsNIP2;2 (Lsi2)

Li et al. (2009)

Shi et al. (2016a)

Xu et al. (2017a)

Xu et al. (2017a)

Song et al. (2014)

Tang et al. (2017)

OsPTR7 
Table 2

Arsenic concentration in irrigation water, soil and different plant tissues worldwide from field experiments.

\begin{tabular}{|c|c|c|c|c|c|c|c|c|}
\hline \multirow[t]{2}{*}{ Country } & \multirow[t]{2}{*}{ Rice variety } & \multirow[t]{2}{*}{ Irrigation water } & \multicolumn{5}{|c|}{ Total As $\left(\mathrm{mg} \mathrm{kg}^{-1}\right)$} & \multirow[t]{2}{*}{ References } \\
\hline & & & Soil & Root & Straw & Husk & Grain & \\
\hline \multirow[t]{9}{*}{ Bangladesh } & BR29 & - & $\sim 15$ & - & 1.7 & - & 0.17 & Dittmar et al. (2010) \\
\hline & & & & & $(0.3-8.5)$ & & $(0.08-0.43)$ & \\
\hline & - & $68-136$ & $11.41-61.04$ & - & $0.571-1.916$ & 0.380 & - 0.182 & Hossain et al. (2008) \\
\hline & & & & & & 0.995 & 0.436 & \\
\hline & Boro and Aman & - & - & - & $2.64-12.52$ & $1.20-2.48$ & $0.22-0.81$ & Khan et al. (2010a) \\
\hline & - & $5.1-77.4$ & $9.8-13$ & - & 2.1 & - & 0.23 & Rahman et al. (2010) \\
\hline & BRRI dhan28 & 70 & 14.5 & 46.3 & 1.7 & - & 0.6 & Rahman et al. (2007b) \\
\hline & BRRI hybrid dhan & & & 51.9 & 1.9 & - & 0.7 & \\
\hline & 1 & & & & & & & \\
\hline
\end{tabular}




\section{Cambodia}

China

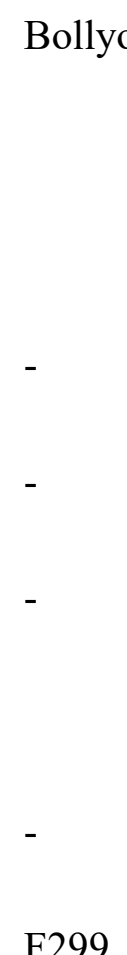

$0.8-18$

3

$(0.1-45.9)$

$6-253$

7.32

(2.5 - 19.2)

110

F299
17.9

64.44

$(52.49$
Seyfferth et al. (2014)

$(0.1-0.37)$

0.092

Fu et al. (2011)

$(0.005$

0.309)

4.07

0.22

Williams et al. (2009b)

0.62

Zhu et al. (2008)

0.09

Jiang et al. (2014)

$(0.02-0.18)$

0.7

Chou et al. (2014)

98.9

3.9

1.2

2.01

0.43

Lei et al. (2013) 
83.86)

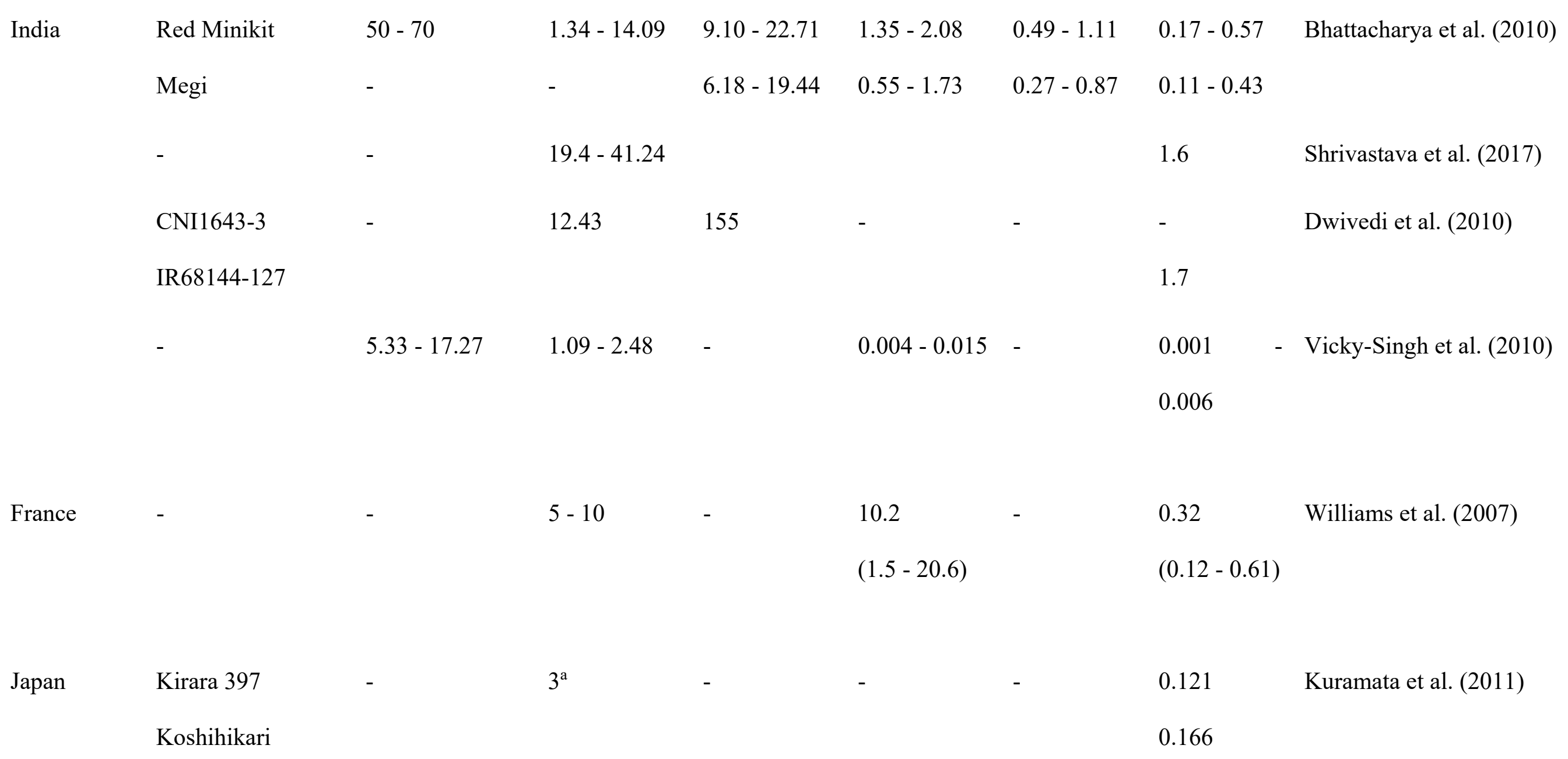




\begin{tabular}{|c|c|c|c|c|c|c|c|c|}
\hline Span & - & - & $4-11$ & - & $\begin{array}{l}3.3 \\
(0.8-9.8)\end{array}$ & - & $\begin{array}{l}0.16 \\
(0.06-0.29)\end{array}$ & Williams et al. (2007) \\
\hline Taiwan & Taigon 2 & $25-67$ & $11.8-112$ & $20.3-188$ & $0.70-5.79$ & $1.05-4.31$ & $0.29-0.66$ & Hsu et al. (2012) \\
\hline USA & - & - & $2-4$ & - & $\begin{array}{l}0.7 \\
(0.4-1.3)\end{array}$ & - & $\begin{array}{l}0.13 \\
(0.08-0.18)\end{array}$ & Williams et al. (2007) \\
\hline
\end{tabular}

a - As concentration in soil solution

The range of total As concentrations is shown in parenthesis 
Table 3

Arsenic speciation in different rice tissues from glasshouse experiments.

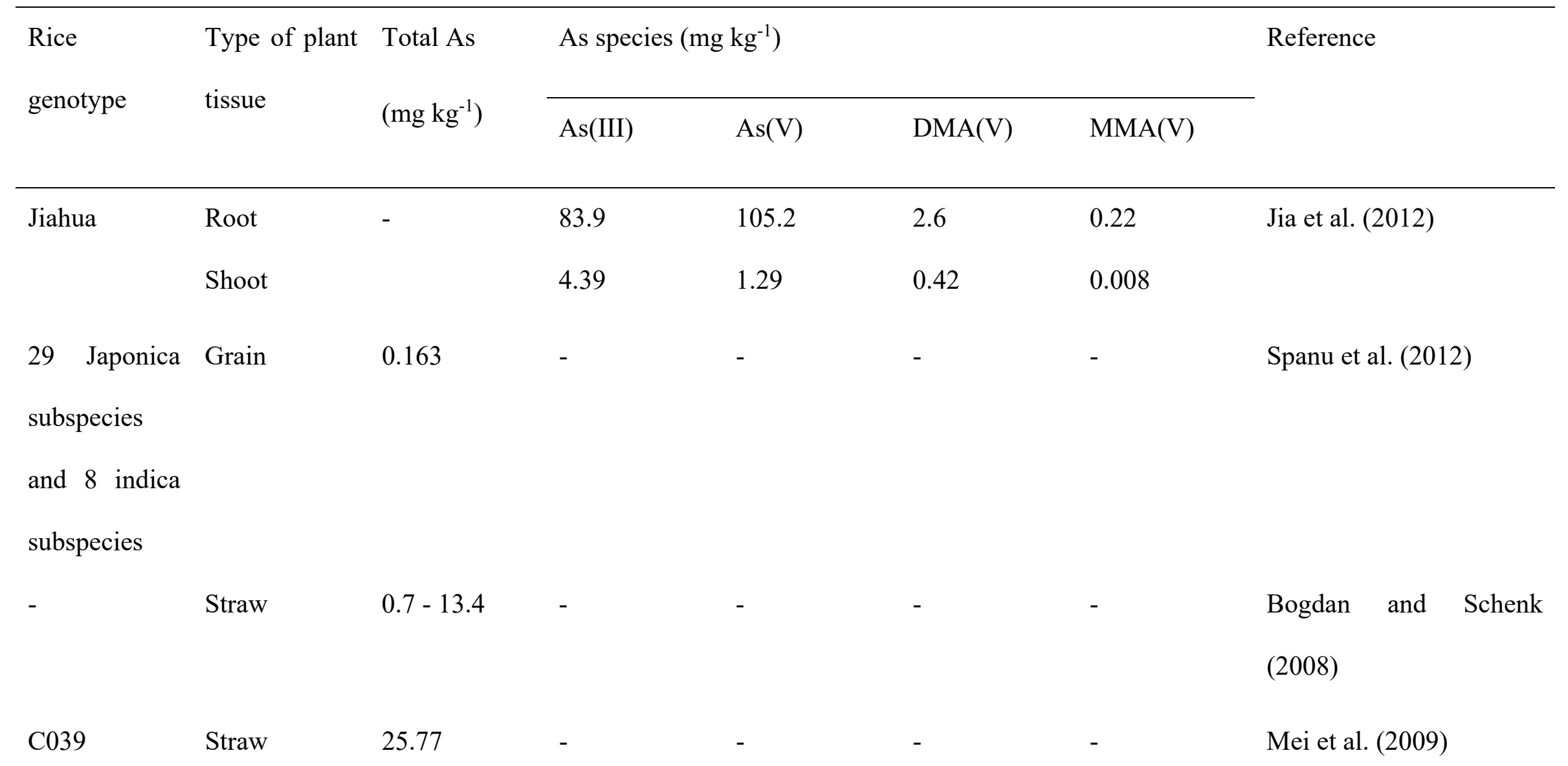




\begin{tabular}{|c|c|c|c|c|c|c|c|}
\hline & Grain & 2.72 & & & & & \\
\hline \multirow[t]{2}{*}{ Guanglua } & Straw & 25.13 & - & - & - & - & \\
\hline & Grain & 2.28 & - & - & - & - & \\
\hline \multirow[t]{2}{*}{ Azucena } & Root & - & - & 13 & 4.6 & 7.1 & Raab et al. (2007) \\
\hline & Shoot & - & - & 2.5 & 4.0 & 1.1 & \\
\hline \multirow[t]{2}{*}{ Bala } & Root & - & - & 26 & 8.9 & 18 & \\
\hline & Shoot & & & 0.2 & 1.0 & 1.1 & \\
\hline \multirow[t]{2}{*}{ BR11 } & Root & 107.5 & - & - & - & - & Abedin et al. (2002) \\
\hline & Straw & 91.5 & - & - & - & - & \\
\hline \multirow[t]{3}{*}{ T116 } & Root & - & 4.25 & 0.55 & 0.16 & 1.95 & Geng et al. (2017) \\
\hline & Stem & - & 0.70 & 0.56 & 1.08 & 1.30 & \\
\hline & Grain & - & 0.83 & - & 0.98 & 0.42 & \\
\hline \multirow[t]{2}{*}{ Y2 } & Root & - & 1.34 & 0.09 & 0.16 & 1.96 & \\
\hline & Stem & - & 0.75 & 0.23 & 0.85 & 0.30 & \\
\hline
\end{tabular}




\begin{tabular}{|c|c|c|c|c|c|c|c|}
\hline & Grain & - & 0.83 & 2.18 & - & - & \\
\hline \multirow[t]{3}{*}{ Quest } & Root & - & $57-78^{a}$ & $16-27^{a}$ & - & - & Smith et al. (2008) \\
\hline & Shoot & - & $32-63^{a}$ & $14-28^{a}$ & - & - & \\
\hline & Grain & - & $1-6^{a}$ & - & $85-94^{a}$ & - & \\
\hline 6 different & Grain & - & $19.8-54.4^{\mathrm{a}}$ & - & $45.6-80.2^{a}$ & - & Syu et al. (2015) \\
\hline \multicolumn{8}{|l|}{ genotypes } \\
\hline Shatabdi & Grain & - & $33-77^{a, b}$ & & $23-67^{a}$ & - & Khan et al. (2010b) \\
\hline \multirow[t]{2}{*}{ M-206 } & Bran & - & & $69-88^{a}$ & $12-3^{a}$ & - & Seyfferth et al. (2011) \\
\hline & Germ & - & $20^{\mathrm{a}}$ & $80^{\mathrm{a}}$ & - & - & \\
\hline
\end{tabular}




\section{Table 4}

Arsenic speciation in market-based rice in different countries.

\begin{tabular}{|c|c|c|c|c|c|c|c|c|}
\hline \multirow[t]{2}{*}{ Country } & \multirow{2}{*}{$\begin{array}{l}\text { Rice } \\
\text { product }\end{array}$} & \multirow{2}{*}{$\begin{array}{l}\text { Number of } \\
\text { samples }\end{array}$} & \multicolumn{4}{|c|}{ As species $\left(\mu \mathrm{g} \mathrm{kg}^{-1}\right)$} & \multirow{2}{*}{$\begin{array}{l}\text { Total As } \\
\left(\mu \mathrm{g} \mathrm{kg}^{-1}\right)\end{array}$} & \multirow[t]{2}{*}{ Reference } \\
\hline & & & As(III) & $\mathrm{As}(\mathrm{V})$ & $\operatorname{DMA}(\mathrm{V})$ & MMA(V) & & \\
\hline \multirow[t]{2}{*}{ Bangladesh } & - & 29 & 129 & 66 & 14 & 2 & 283 & Halder et al. (2014) \\
\hline & & & $(3-402)$ & $(7-570)$ & $(0-53)$ & $(0-3)$ & $(28-961)$ & \\
\hline \multirow[t]{2}{*}{ China } & - & 43 & 107.1 & 4.7 & 9.6 & 0.3 & 129.4 & Ma et al. (2016) \\
\hline & & & $(44.5-197.7)$ & $(0.0-23.8)$ & $(1.4-30.6)$ & $(0.0-2.8)$ & $(50.2-253.0)$ & \\
\hline Italy & - & 61 & 91 & 8.2 & 55 & - & 162 & Tenni et al. (2017) \\
\hline Taiwan & White rice & 51 & 61.6 & 4.3 & 12.1 & 2.7 & 116.6 & Chen et al. (2016a) \\
\hline
\end{tabular}




\begin{tabular}{|c|c|c|c|c|c|c|c|c|}
\hline \multirow[t]{2}{*}{ Australia } & $\begin{array}{l}\text { Brown rice } \\
\text { (whole, }\end{array}$ & 3 & \multicolumn{2}{|c|}{$178^{\mathrm{a}}$} & $\begin{array}{l}68 \\
(65-71)\end{array}$ & $<\mathrm{dl}$ & $\begin{array}{l}287 \\
(290-284)\end{array}$ & Rahman et al. (2014) \\
\hline & $\begin{array}{l}\text { medium } \\
\text { grain) }\end{array}$ & & & & & & & \\
\hline USA & $\begin{array}{l}\text { White long } \\
\text { grain }\end{array}$ & 7 & $\begin{array}{r}98 \\
(62-\end{array}$ & 34) & $\begin{array}{l}157 \\
(85-229)\end{array}$ & $<\mathrm{dl}$ & $\begin{array}{l}264 \\
(85-344)\end{array}$ & $\begin{array}{l}\text { Heitkemper et al. } \\
(2009)\end{array}$ \\
\hline South Korea & Brown rice & 30 & 80 & 5 & 30 & 2 & - & Kim et al. (2013) \\
\hline Nigeria & - & 23 & \multicolumn{2}{|c|}{$47^{\mathrm{a}}$} & 11.5 & 0.33 & 58.8 & Adeyemi et al. (2017) \\
\hline Thailand & White rice & 79 & $\begin{array}{l}81.44 \\
(14.29-153.73)\end{array}$ & $\begin{array}{l}3.74 \\
(<2.0-7.85)\end{array}$ & $\begin{array}{l}29 \\
(2.42-85.95)\end{array}$ & $\begin{array}{l}<2 \\
(<2.0-6.40)\end{array}$ & $\begin{array}{l}139.48 \\
(22.51 \\
304.32)\end{array}$ & $\begin{array}{l}\text { Nookabkaew et al. } \\
\text { - (2013) }\end{array}$ \\
\hline India & Red rice & - & \multicolumn{2}{|c|}{$50^{\mathrm{a}}$} & 10 & $<\mathrm{dl}$ & 80 & Williams et al. (2005) \\
\hline Japan & $\begin{array}{l}\text { Rice } \\
\text { noodles }\end{array}$ & 6 & \multicolumn{2}{|c|}{$120^{\mathrm{a}}$} & \multicolumn{2}{|c|}{$20^{\mathrm{b}}$} & 190 & Sun et al. (2009a) \\
\hline Japan & Rice & 11 & \multicolumn{2}{|c|}{$210^{\mathrm{a}}$} & \multicolumn{2}{|c|}{$70^{\mathrm{b}}$} & 390 & Sun et al. (2009a) \\
\hline
\end{tabular}




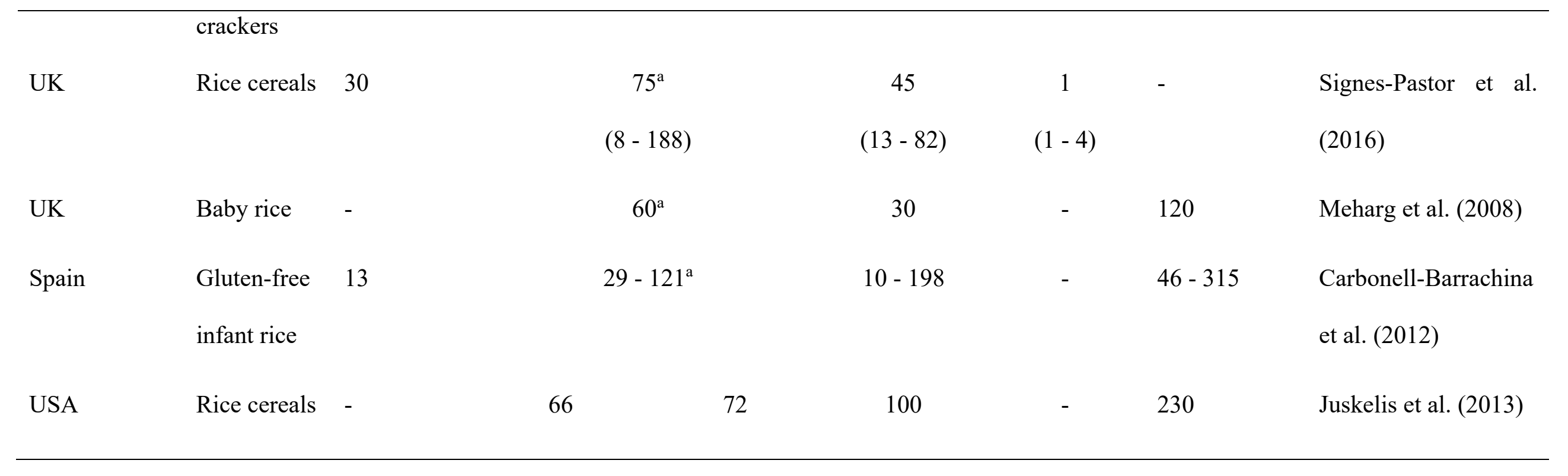

\begin{abstract}
a - sum of $\mathrm{As}(\mathrm{III})$ and $\mathrm{As}(\mathrm{V})$
$\mathrm{b}$ - sum of DMA(V) and MMA(V)

$\mathrm{dl}$ - below the detection limit
\end{abstract}

The range of concentration for respective As species is shown in parenthesis 


\section{Figure captions}

Fig. 1. Genes involving in inorganic and methylated As species uptake, transformation, and localization in rice plant. 


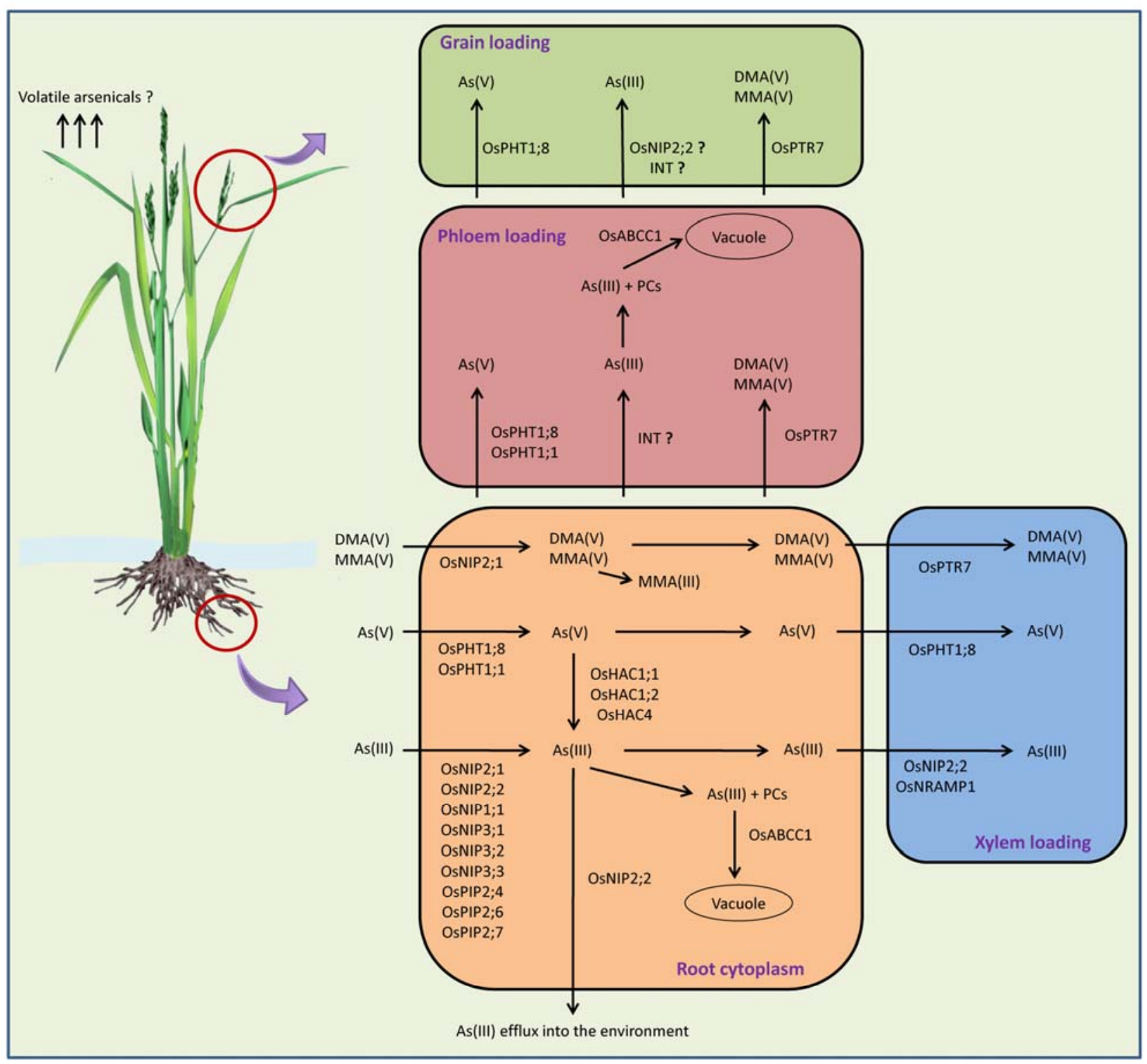

Fig. 1. Genes involving in inorganic and methylated As species uptake, transformation, and localization in rice plant. 